\title{
BIBLIOMETRIC STUDIES IN TOURISM
}

\author{
Mehmet Ali Koseoglu, PhD \\ School of Hotel and Tourism Management \\ The Hong Kong Polytechnic University \\ Kowloon, Hong Kong \\ Email: mehmetali.koseoglu@polyu.edu.hk \\ Email: trmaliktr@yahoo.com \\ Roya Rahimi, $\mathrm{PhD}$ \\ Lecturer in Tourism and Hospitality Management \\ Department of Marketing, Innovation, Leisure and Enterprise \\ University of Wolverhampton, UK \\ Email: Roya.Rahimi@wlv.ac.uk \\ Fevzi Okumus, $\mathrm{PhD}$ \\ Rosen College of Hospitality Management \\ University of Central Florida \\ Orlando, USA \\ Email: Fevzi.Okumus@ucf.edu \\ Prof. Jingyan Liu \\ Hospitality \& Service Management Department \\ Business School \\ Sun Yat-Sen University \\ No.135, Xingang West Road \\ Guangzhou, China \\ Email: Ljy6633@126.com
}

Corresponding author: Mehmet Ali Koseoglu 


\section{Highlights}

- This study evaluates progress on bibliometric studies in tourism.

- Systematic review studies emerged as the major group.

- Relatively few studies utilized evaluative and relational bibliometric studies.

- Samples of bibliometric studies were formed from articles mainly indexed by SSCI.

- The main implication is that unknown patterns have not been revealed. 


\title{
BIBLIOMETRIC STUDIES IN TOURISM
}

\begin{abstract}
This study evaluates bibliometric studies in tourism, depicts emerging themes, and offers critical discussions for theory development and future research. To achieve this aim, 190 papers with bibliometric analyses from leading hospitality and tourism journals were selected and critically analyzed. The research findings reveal that bibliometric articles published in these journals significantly increased after 2008. However, systematic review studies emerged as the major group, and relatively few studies utilized evaluative bibliometric and relational bibliometric studies. Study results suggest that paucity still exists, particularly in relational bibliometric studies in tourism. This is one of the first studies in this area that offers critical discussions and suggestions related to theory development and future research in this research vein.

Keywords: Tourism, Bibliometric Studies, Review, Co-Citation, Co-Authorship.
\end{abstract}




\section{INTRODUCTION}

Scholars have been vetting the epistemology, knowledge domain, and/or intellectual structure of disciplines to elucidate how they have evolved over time. Since many disciplines have reached a level of maturity (Koseoglu, 2016), there has been a significant interest in evaluating and monitoring the evolution of disciplines based on given topics with the assistance of advanced software programs (Koseoglu et al., 2015a; Zupic \& Čater, 2015). Hence, bibliometry or bibliometric analysis is being increasingly used to map the structure and development of scientific fields or disciplines to assess the evolution of specific disciplines (Boyack et al., 2005; Zupic \& Čater, 2015).

Bibliometric is defined as an approach to evaluate and monitor the progress of given disciplines by sorting data, including citations, author affiliations, keywords, themes discussed, and methods employed for published studies in the disciplines via basic/advanced statistical techniques (Diodato, 1994; McBurney \& Novak, 2002). Numerous studies have been conducted by utilizing bibliometric methods to illuminate methods, prolific and influential scholars and/or institutions, intellectual structure, the knowledge domain by year, the geographic area of different disciplines, specific research themes within disciplines, and the level of maturity of topics (e.g., Barrios et al., 2008; Benckendorff, 2009; Chan \& Hsu, 2016; Fagerberg et al., 2012; Fong et al., 2016; Gomezeli, 2016; Gregory \& Weinland, 2016; Howey et al., 1999; Landstrom et al., 2012; Meyer-Arendt \& Justice, 2002; Page, 2003; Palmer et al., 2005; Park, et al., 2011; Ye et al., 2013).

As seen in other disciplines, in tourism there have been ongoing attempts to discuss whether tourism is a scientific discipline, or field of study, or specialism since tourism studies have been accepted fragmented, scattered, and/or eclectic (Belhassen \& 
Caton, 2009; Benckendorff \& Zehrer, 2013; Xiao \& Smith, 2006a). Hence, to illustrate the maturity level of tourism, bibliometric studies have been conducted in the tourism field to identify intellectual structure, academic foundation, knowledge domain, or social structure of the field (Benckendorff, 2009; Benckendorff \& Zehrer, 2013; Hu \& Racherla, 2008; Koseoglu et al. 2015a; Ye et al., 2013) and to rank the most productive scholars, institutions, and publications (McKercher et al., 2006; Page, 2005; Park et al., 2011; Pearce, 1992; Pechlaner et al., 2002, 2004; Ryan, 2005; Schmidgall, et al., 2007; Sheldon, 1991; Zhao \& Ritchie, 2007). However, no study has yet been conducted on how bibliometric studies have evolved in the tourism field to discuss the following questions:

- What are the research implications of bibliometric structures?

- What are the potential challenges and barriers to bibliometric studies?

- Who benefits the most by new sorts of bibliometric studies?

- How can bibliometric studies impact theory development?

- How can bibliometric studies change the politics and future research in the field?

In this article, we aim to investigate these issues in the tourism field. The paper is structured as follows. First, an in-depth literature review is provided on bibliometric and bibliometric methods, establishing an overview of studies conducted via bibliometric methods. Second, the research method employed for this study is explained. Next, the research findings are presented and discussed. Finally, the study conclusions and suggestions for future studies are provided.

\section{LITERATURE REVIEW}

\subsection{What is Bibliometric Analysis?}


Broadus (1987, p. 376) defines bibliometric as "the quantitative study of physical published units, or of bibliographic units, or of the surrogates for either." Gupta (1988) refers to bibliometric as the organization, classification, and quantitative evaluation of publication patterns of all macro and micro communication along with their authorships by mathematical and statistical calculus. Bibliometric is a tool to analyze how disciplines evolve based on intellectual structure, social structure, and conceptual structure (Zupic \& Čater, 2015). It looks at research outputs, including themes sought, methods employed, and samples used (Ye et al., 2012), via applying basic or advanced statistical techniques to the data obtained from previously published studies, such as books, proceedings, and journals (Cobo et al., 2011a; Diodato, 1994; McBurney \& Novak, 2002).

\subsection{Bibliometric Impacts and Uses}

Bibliometric is "one of the rare truly interdisciplinary research fields to extend to almost all scientific fields" (Glanzel, 2003, p. 3). Zupic and Čater (2015) suggest that bibliometric methods are complementary to traditional methods of review and structured literature reviews, and when compared with these bibliometric methods, they increase the objectivity of these types of studies. Bibliometric is used to assess the performance of the research and publication of individuals and/or institutions, and/or map the structure and dynamics of science (Cobo et al., 2011). Hence, bibliometric studies can help researchers answer the following questions (Nerur et al., 2008; Zupic and Čater, 2015; Ye et al., 2012): (a) What is the intellectual structure of the discipline and how does it evolve? (b) What is the social structure of the discipline? (c) What are the conceptual structures of the discipline? (d) What is the best way to evaluate research output? (e) How should the impacts of researchers and institutions be assessed? (f) How 
is the given discipline progressing on themes sought, methods employed, and samples used? By answering these questions, potential subjective biases are minimized and expert inferences are validated, leading to schools of thought and the interrelated connections among them being delineated.

There are three groups of scholars who use bibliometric and undertake bibliometric studies. The first group consists of bibliometricians, and scholars in this group engage in the methodology of bibliometric and conduct, mainly methodological research on this topic. The second group of scholars is made up of researchers from different disciplines that use bibliometric in their specialty, scientific information. This is the most diverse interest group in bibliometric. These researchers expand science information by using metrics and conducting quantitative research in information retrieval. Researchers in the third group use bibliometric for science and policy making. They evaluate the foundation of science by illustrating the national, regional, and institutional structures of disciplines (Glanzel, 2003).

\subsection{Bibliometric Methods}

Bibliometric methods vary from basic mathematic rules to advanced statistical applications. There are different categories for bibliometric methods. For instance, according to Koseoglu et al. (2015a), there are two bibliometric methods. The first is the basic bibliometric technique, in which the researcher reviews studies via content analysis and metrics to measure the performance of the papers and/or contributors. The second advances a variety of methods, which include co-occurrence approaches such as co-citation analysis, co-authorship analysis, and co-word analysis. 
Benckendorff and Zehrer (2013) also refer to two bibliometric methods: (a) evaluative techniques and (b) relational techniques. Evaluative techniques focus on the impact of academic studies by assessing performance with productivity measures, impact metrics, and hybrid metrics (Hall, 2011). Relational techniques delve into relationships among published research by considering their citations, authors, author affiliations, and keywords to conduct co-occurrence analyses. These techniques help researchers and readers elucidate the intellectual structures of the fields, the social structures of the fields, and the emergence of new research topics (Leydesdorff \& Vaughan, 2006; Nerur et al., 2015; Pilkington \& Lawton, 2014; Ronda-Pupo \& Guerras-Martín, 2012; Tan \& Ding, 2015).

By synthesizing the guidelines from 81 bibliometric studies in management and organization, Zupic and Čater (2015) developed a single-source reference for management and organization scholars interested in bibliometric methods. They recommended workflow guidelines for carrying out bibliometric studies and their findings were used as one of the main resources for completing this paper. Therefore, in their study, bibliometric studies are categorized into three groups: (1) review studies, (2) evaluative studies, and (3) relational studies (Figure 1).

Insert figure 1 about here

Review techniques include structured literature reviews, systematic literature reviews, or meta-analyses/reviews, all of which are called traditional review methods (Zupic \& Čater, 2015). They generate knowledge by using bibliographic data from published studies via frequency analysis or basic statistics. In addition to this, these techniques use a qualitative approach to assess the evolution of the disciplines. They 
may present a research agenda or a framework depicting the evolution in a given topic based on the authors' individual views. Hence, the subjectivity is high in this technique. To minimize this subjectivity, evaluative techniques, and relational techniques are proposed.

Evaluative techniques measure the impact of scholarly work when compared to the performance or scientific contributions of two or more individuals or groups (Benckendorff \& Zehrer, 2013). Hall (2011) classifies evaluative metrics into three groups. The first group includes productivity measures, such as the number of cited papers, the number of papers per academic year, and the number of papers per individual author. The second category includes impact metrics, such as the total number of citations, number of citations per academic year, number of citations per individual author/journal, and usage log data (i.e., usage impact factors that consists of average usage rates for the articles published in a journal). The third group consists of hybrid metrics, such as an average number of citations per paper as well as various indices that aim to capture both productivity and impact in a single figure.

Relational techniques explore relationships among the research fields, the emergence of new research themes and methods, or co-citation and co-authorship patterns (Benckendorff \& Zehrer, 2013). Relation techniques can be divided into four categories: co-citation analysis, co-word analysis, co-authorship analysis, and bibliographic coupling. These categories will be briefly explained below.

Co-citation analysis uses co-citation counts to construct measures of similarity between documents, authors, or journals (McCain, 1990). According to Small (1973), co-citation refers to the frequency with which two units are cited together. There are different types of co-citation, including author co-citation analysis and journal co- 
citation analysis (McCain, 1990; White \& Griffith, 1981; White \& McCain, 1998). Cocitation analysis is used to evaluate the intellectual structure of different disciplines, such as marketing (Jobber and Simpson, 1988), operations management (Pilkington \& Fitzgerald, 2006), services management (Pilkington \& Chai, 2008), and tourism (Benckendorff, 2009).

Bibliographic coupling uses the number of references shared by two documents as a measure of the similarity between them (Zupic \& Čater, 2015). Co-author analysis examines the networks that scientists create socially by collaborating on scientific articles (Acedo et al., 2006). Co-author analysis is particularly suitable for studying research questions involving scientific collaboration (Benckendorff, 2010; Racherla \& Hu, 2010; Ye et al., 2013).

Co-word analysis is a content analysis technique that uses the words in documents to establish relationships and build a conceptual structure of the domain (Callon et al., 1983). The idea underlying the method is that when words frequently cooccur in documents, it means that the concepts behind those words are closely related too. The output of co-word analysis is a network of themes and their relations that represent the conceptual space of a field. This semantic map can help researchers understand its cognitive structure (Borner et al., 2003). A series of such maps produced for different time periods can trace the changes in this conceptual space (Coulter et al., 1998).

\subsection{Bibliometric Studies in Tourism}

The greatest utilization of bibliometric in tourism literature is with respect to the evaluation of journals and those who publish in them (Hall, 2011). On the other hand, there are several related studies published in the bibliometric literature (see: Barrios et 
al., 2008; Tokić \& Tokić, 2015; Zhang et al., 2015; Zopiatis et al., 2015). Additionally, several previous studies analyzed graduate dissertations in tourism studies (Bao, 2002; Hall, 1991; Laing \& Weiler, 2008; Meyer-Arendt, 2000; Meyer-Arendt \& Justice, 2002). Koseoglu et al. (2015a) and Koseoglu et al. (2015b) divided previous tourism bibliometric analysis into six categories: journals assessment and ranking studies, article identification studies, content analysis, citation analysis, disciplinal relationship analysis, and country research analysis. However, the progress of these bibliometric studies in tourism and how they influence the knowledge domain of the field or theory development have not been elucidated. Therefore, this current study aims to address this gap in the field.

\section{METHODOLOGY}

\subsection{Databases and Journals Selection}

Articles published in leading scientific journals are accepted as "certified knowledge" (Ramos-Rodrigues \& Ruis-Navarro, 2004). Therefore, leading tourism journals were selected as a sample for this current study. Articles related to bibliometric studies were obtained from leading hospitality and tourism journals ranked by SSCI in 2014. In particular, nine hospitality and tourism journals with high impact factors were selected. Five of these nine journals were tourism-focused journals, and four of them were more hospitality-focused. These journals are also recognized as leading journals in bibliometric studies in the tourism field (Harrington \& Ottenbacher, 2010; Ip et al., 2011; Koseoglu et al. 2015a; Koseoglu et al., 2015; Morasan et al., 2014; Racherla \& $\mathrm{Hu}, 2010)$. The five leading tourism journals selected for this study were the Annals of Tourism Research (ATR), the Journal of Sustainable Tourism (JST), Tourism Management (TM), the Journal of Travel Research (JTR) and the International Journal 
of Tourism Research (IJTR). The four leading hospitality journals selected for this study were the International Journal of Hospitality Management (IJHM), Cornell Hospitality Quarterly (CHQ), the International Journal of Contemporary Hospitality Management (IJCHM) and the Journal of Hospitality and Tourism Research (JHTR).

\subsection{Data Collection and Analysis}

Three steps were followed to identify the bibliometric studies published in these nine journals. First, the first author of this study scrutinized titles of all articles published in the above-named journals from the first issue of each journal through issues published by December 2015 by screening keywords, including review, metaanalysis, mapping, path, visualization, bibliometric, scientometrics, informetrics, networks, co-author, co-citations, co-word, co-occurrence, and bibliographic coupling, in titles of all the articles. Second, by adding one more keyword "meta-review," identified from the first scan, all given keywords were scanned in titles, keywords, and abstracts of all articles published in the nine journals. Last, two authors of the study examined articles sorted out from databases to determine whether they were conducted via bibliometric analysis or review studies. To end this, these authors individually answered the question, "Is the article conducted via bibliometric analysis or is it a review study?" to ensure data validity and reliability by reaching consensuses on the articles selected. As a result, a total of 190 studies, published between 1988 and 2015, including full-length articles and research notes, were found for the purpose of this study. A spreadsheet was created to analyze the articles by employing content analysis for each article. It included data about the types of bibliometric methods, time periods used, types of samples utilized, databases used to extract bibliometric data, bibliometric software used, themes investigated, kinds of sources (documents, authors, and journals) 
used to gather data, bibliometric methods used to highlight subgroups, visualization methods, and software utilized.

\section{RESULTS}

\subsection{Analysis of Reviewed Articles}

As noted earlier, bibliometric studies were evaluated based on review studies, evaluative studies, and relational studies (Zupic \& Čater, 2015). Following this, the bibliometric analysis of the articles found in this process revealed 157 review studies. In other words, the review studies had the highest percentage of the 190 articles, followed by 24 evaluative studies and nine relational studies. While the number of articles conducted via bibliometric methods significantly increased after 2008, systematic review studies emerged as the major group in the whole period. On the other hand, although relational techniques were first used in 2008 based on the sample group of the study, only nine articles utilizing relational techniques were produced. The techniques included co-citation (three articles) (Koseoglu et al. 2015a; Benckendorff \& Zehrer, 2013; Xiao \& Smith, 2008), bibliographic coupling (two articles) (Yuan et al. 2014a; Yuan et al. 2014b) - Xiao \& Smith's (2008) study utilized bibliographic coupling as well as co-citation-, co-authorship (three articles) (Hu \& Racherla, 2008; Racherla \& Hu, 2010; Ye, Li, \& Law, 2013), and co-word (one article) (Ying \& Xiao, 2012).

Insert figure 2 about here

Figure 3 demonstrates the distribution of the articles by journals and years. Of the 190 articles analyzed, $T M$ produced the highest number of bibliometric articles (45), followed by IJCHM (34), IJHM (34), ATR (26), IJTR (14), CHQ (10), JHTR (10), JTR 
(9), and JST (8). While the number of articles published in these journals increased after 2007, IJCHM emerged as the major journal publishing these articles in its special issues in recent years.

Insert figure 3 about here

As shown in Figure 4, all journals published articles conducted via review analysis and evaluative analysis, except for IJHM. A total of eight articles conducted via relational techniques were published, including three by ATR (Benckendorff \& Zehrer, 2013; Racherla \& Hu, 2010; Yuan et al., 2014a; Xiao \& Smith, 2008), followed by two from IJHM (Hu \& Racherla, 2008; Koseoglu et al., 2015a), two from JHTR (Ye et al., 2013; Ying \& Xiao, 2012), and one from IJTR (Yuan et al., 2014b). CHQ, IJCHM, JST, $J T R$, and TM had no articles conducted via these relational techniques.

Insert figure 4 about here

In all of these articles, multiple time periods were not generally preferred. To form the sample of the studies, articles published in leading tourism journals were mainly preferred instead of books and proceedings. As seen, other bibliometric studies concluded in other fields (see: Meho \& Yang, 2007; Nerur et al., 2008; Zupic \& Čater, 2015), journals were selected from mainly SSCI, and/or rarely Google Scholar, and/or Scopus due to the reputation of SSCI among scholars and the design of databases for bibliometric analysis (McKercher \& Tung, 2015; Hall, 2011; Koseoglu et al., 2015a). In this sample, authors evaluated mainly the context of the documents (articles) rather than authors (prolific and leading) or journals (e.g., rank and quality). In relational techniques, CATAR, Bibexcel, and Sitkis software programs were used to extract the 
data obtained from the databases. To highlight subgroups, clustering and network methods were conducted, and the visualization methods and software were network analysis, Pajek, and UCINET.

\subsection{The State of the Art in Bibliometric Studies of Tourism}

This section provides discussions on how bibliometric studies progress in tourism under three subtitles: review studies, evaluative studies, and relational studies.

\subsubsection{Review Studies}

As discussed earlier, review studies are classified as disciplined-focused, themefocused, methodology/method/statistics-focused, sample-focused, contributor-focused, and journal-focused studies (Koseoglu et al. 2016)

\section{Disciplined-Focused Review Studies}

Discipline-focused studies include articles that assess the progress on the entire tourism area by focusing on one or more dimensions. For instance, Eccles and Costa (1996) examined the themes on articles published in ATR, TM, and Travel and Tourism Analyst during 1989-1995. Xiao and Smith (2006b) sought the major subject areas on articles published in ATR between 1973 and 2003. They found 27 major subjects and identified two meta-categories of subject domains as "methodology and theory" and “development and impacts." Wickham, Dunn, and Sweeney (2012) assessed three leading tourism journals $(A T R, T M$, and $J T R)$ to identify research themes in tourism between 1999 and 2008. They identified the 12 most popular themes, including business development, tourist behavior, consumer behavior, attractions, hospitality management, niche-tourism, cultural tourism, impacts of tourism, external influences, transportation, 
related industries, and tourism education. In another study, Pearce (2014) investigated the internationalization of tourism research by comparing articles published in the Journal of Travel Research and Estudios y Perspectivas de Turismo.

A few studies have assessed the progress on hospitality research in the leading hospitality-focused journals. Blum (1997) discussed the progress of six themes: people and organizations, service quality and customers, strategy and operations, food service, education, and eco-tourism and legal issues. Other studies (Chon et al., 1989; CrawfordWelch, 1992; Baloglu \& Assante, 1999) identified both subject areas and research methods in the field. It appears that there is a gap in the tourism and hospitality research, as there is no review on how the fields have been progressing by considering bibliometric indicators, such as themes discussed, methods employed, samples used, and contributors over time.

\section{Theme-Focused Review Studies}

Theme-focused studies include articles on discussing how one or more themes, such as marketing or human resources, have evolved in the entire discipline. Table 1 presents these studies based on related subdisciplines. These studies assessed the progress of the theme by using bibliometric indicators (e.g., Lucas \& Deery, 2004; Morosan et al., 2014; Oh et al., 2004; Song \& Li, 2008; Yoo \& Bai, 2013) or suggested new frameworks on the themes and/or research agendas (e.g., Kandampully et al., 2015; Tracey, 2014; Kim, Wang, \& Mattila, 2010; Ashworth \& Page, 2011; Morrison, 2002; Law, Qi, \& Buhalis, 2010).

As presented in Table 1, theme-focused review studies varied from marketing to tourism history, or from travel medicine to demand issues. Subdisciplines and subjects 
related to the business and management dimension of tourism have mainly been reviewed (Athiyaman, 1995). Other dimensions of tourism, such as human factors (e.g., psychology and health), and place (e.g., geography, roads, airports, and the environment) (Athiyaman, 1995) have rarely been discussed. The sample of these studies was formed generally from articles published in leading tourism journals or indexed by well-known databases, such as ABI/Inform, Science Direct, Google Scholar, and Ebscohost. Several articles, including Dev et al. (2010) and Harrington et al. (2015), employed longitudinal approaches to evaluate the progress of the subjects or disciplines. A few studies (e.g., Lucas and Deery, 2004) compared the progress of a discipline in hospitality journals with other related journals. Many theme-focused review studies seen in Table 1 have been conducted via qualitative review rather than a quantitative review. There was no study reviewing some important subdisciplines and/or subjects, such as family business, organization theory, and crisis management.

\section{Insert table 1 about here \\ Methodology/Method/Statistics - Focused Review Studies}

Methodology/method/statistics-focused review studies constituted articles directly focusing on how methodology/method/statistics have evolved in the tourism literature. Both macro level and micro level review studies have been conducted. The macro level studies have focused on the progress of research methods in the tourism field. For example, Palmer et al. (2005) ranked 24 most often used statistical methods in articles published in 12 tourism journals between 1998 and 2005. Rivera and Pizam (2015) illuminated the progress of the methodology in hospitality research by combining the qualitative and quantitative review approaches. They used articles 
published between 2000 and 2012 in $I J H M$ for quantitative review. They identified the four phases in this progress as story tellers (1930-1950), profilers (1950-1970), copy cats (1970-2005), and innovators (since 2000).

When the focus shifted to the micro level, Ro (2012) showed the effects of moderator and mediator variables in the hospitality research published in IJHM from 2001 to 2011. Hung and Law (2011) investigated how internet-based surveys were conducted in tourism research indexed in the EBSCO host. They assessed authorship, geographical scales, topics, research designs, and response rates. More specifically, the progress and usage of importance-performance analysis (Azzopardi \& Nash, 2013) and structural equation modeling (Nunkoo et al., 2013) were addressed.

\section{Sample-Focused Review Studies}

Sample-focused review studies focus on studies based on their samples. These studies can be categorized into three groups: industry, people, and place. There are two studies focusing on the industry as samples. While one of them reviewed the food industry and consumer behavior (Johns \& Pine, 2002), the other one reviewed the restaurant industry and revenue management (Thompson, 2010). People-based studies addressed two issues related to children in tourism studies (Poria \& Timothy, 2014) and hotel general managers (Ladkin, 1999).

Place-based studies generally focused on the progress of the tourism literature related to a country. For instance, Carter et al. (2015) looked at progress in Cambodia's sustainable tourism. Silva et al. (2010) and Galani-Moutafi (2004) provided research agendas for Portugal and Greece, respectively. Hing (1997) and Hing and Dimmock (1997) demonstrated thematic development in the Asia-Pacific region. More studies focused on China have related to hotel development (Kong \& Cheung, 2009), service 
quality research (Tsang et al., 2015), pro-poor tourism (Zeng \& Ryan, 2012), and hospitality research (Law et al., 2014; Tsang \& Hsu, 2011). Tsang and Hsu (2011) focused on authorship, contributors, and methodological procedures in six leading tourism and hospitality journals (English language) published from 1978 to 2008. These review studies generate opportunities for researchers to contribute to the fields by comparing evaluations of the literature based on people, industry, and place.

\section{Contributor-Focused Review Studies}

Contributor-focused review studies demonstrate the leading authors in the fields (e.g., Zhao \& Ritchie, 2007) and the leading institutions or countries (e.g., Jogaratnam et al., 2005a; Jogaratnam et al., 2005b). Additionally, these studies assessed editorial contributions in the field (e.g., Law et al., 2010). Jogaratnam et al. (2005b) provided a comprehensive assessment of institutional contributions to 11 leading tourism hospitality journals.

\section{Journal-Focused Review Studies}

Journal-focused review studies show the evolution of journals. For example, Lu and Nepal (2009) analyzed JST longitudinally by considering several bibliometric indicators, including journal expansion, study location, volume, number, year, areas, forms of tourism, subject themes, research perspectives, concept and measurement, and methodology. Law et al. (2012) evaluated the progress of $C H Q$ from 2008 to 2011 on research fields, affiliated hospitality sectors, data collection methods, major data analysis methods, geographical coverage, data collection countries, regions, number of authors, positions of authors, and institutions with the greatest number of contributions. Svensson et al. (2009a, 2009b) assessed six tourism journals based on empirical and 
scientific characteristics, respectively. Finally, Rivera and Upchurch (2008) utilized articles published in $I J H M$ between 2000 and 2005. They sorted the articles out into five groups (policy research, managerial research, evaluation research, action research, and operational research) and then assessed them via bibliometric indicators.

\subsubsection{Evaluative Studies in Tourism}

Twenty-four studies were found that used at least one evaluative indicator to assess progress in the tourism literature. They may be accepted as review studies. However, these studies are different from review studies, as they may be conducted via at least one evaluative technique or an advanced statistical method as well as frequency analysis. These studies used one or more indicators to evaluate the progress in the field from groups including productivity, impact, and hybrid measures. Hence, the usage of the measures varied and overlapped in the studies. These studies particularly focused on the development of tourism journals (Cheng et al., 2011; Jamal et al., 2008; Law \& van der Veen, 2008; Ryan, 2005), productivity of authors (McKercher \& Tung, 2015; Zhong et al., 2015; Park et al., 2011, Ryan, 2005; Sheldon, 1991), ranks and positions of authors (Sheldon, 1991), productivity in a research field (Ballantyne et al., 2009; Carter et al., 2001; Frew, 2000; Figueroa-Domecq et al., 2015), and contributors as universities and countries (Park et al., 2011; Page, 2003; Sheldon, 1991). Weiler et al. (2012) studied the growth of disciplines that influence tourism doctoral research from four online databases that catalog and inventory doctoral research in the United States, Canada, Australia, and New Zealand.

Several studies have focused on citations to assess the impacts of articles, authors, or journals, including citation sources and/or frequency (Dev et al., 2010; 
Howey et al., 1999; Kim et al., 2009; McKercher \& Tung, 2015), tourism citations in other disciplines (Wardle \& Buckley, 2014), main paths in a subject (Chuang et al., 2014), and ranking of cited journals and age of citations (Crouch \& Perdue, 2014). According to the research findings, bibliometric studies using hybrid measures were rare. These studies ranked journals (Hall, 2011; Murphy \& Law, 2008), or authors (McKercher, 2008) via an h-index and/or a g-index. In this respect, one might ask why these types of studies using metrics (i.e. number of papers, citations, indices, web hits, view counts, etc.) are rare. One of the main reasons is that although authors produce a number of related studies, these type of studies are rejected by editors/ reviewers since such rankings are now readily available in real time and studies repeating this data add little value. Another reason is that the philosophy of these methods conducted in studies is not reflected or integrated into the studies to add value.

Zhong et al. (2015) investigated research on China's tourism based on authorship analysis in subperiods between 1978 and 2012. For example, Page (2003) assessed the research performance of universities in the United Kingdom. Yet, there is still a paucity of studies focusing on the evaluation of literature in certain countries and in the general management and/or the tourism literature. On the other hand, only three themes in tourism have been assessed by evaluation measures, including medical tourism (Chuang et al., 2014), resource management (Carter, 2001), and information and communications technology (Frew, 2000). Additionally, hospitality marketing was sought via citation analysis based on one journal (Dev et al., 2010).

\subsubsection{Relational Studies in Tourism}


In recent years, the interest in relational studies has been increasing in the management literature. However, in the tourism literature, only eight articles were found. These studies are assessed and discussed below.

\section{Studies conducted via co-citation analysis}

Although co-citation analysis is a popular method in other disciplines (Zupic \& Čater, 2015), only three research studies were conducted via this method in the selected tourism journals. For example, Xiao \& Smith (2008) investigated the knowledge impacts of 17 scientific literature classics in the sociology and anthropology of tourism via co-citation and bibliographical coupling analysis. They found that these titles had a strong and lasting impact on academics. Benckendorff and Zehrer (2013) identified influential authors, studies, and ranked scholars via co-citation network analysis. They used the reference lists of studies published in three leading tourism journals (ATR, JTR, and $T M$ ) between 1996 and 2010 by extracting data via the Sitkis package program and visualizing via the UCINET package program. They found that the social sciences have been influential in the field. However, they also found that business-related citations were increasing.

Koseoglu et al. (2015a) conducted a citation and a journal co-citation analysis to explore the academic foundations of tourism from reference lists of articles focusing on an emerging country, Turkey. They extracted the data from articles related to Turkey published in nine leading tourism journals indexed within the SSCI category, including ATR, CHQ, Current Issues in Tourism, IJCHM, IJHM, IJTR, JHTR, the Journal of Travel and Tourism Marketing, and TM. They analyzed the data obtained on the articles published from the journals' first issues to the last issues by 2013 via Excel, Bibexcel, 
SPSS, and Pajek software programs. They observed changes in the academic foundation of tourism research with regard to Turkey and visualized these changes by creating subperiods (2000-2006 and 2007-2013). They found that over half of the citations were from publications engaging outside of the tourism field and cited similar patterns among hospitality/tourism, marketing, and psychology fields. However, it was found that the intradisciplinary maturity constituted by the tourism journals was weak.

\section{Studies Conducted via Bibliographic Coupling Analysis}

Two studies conducted via bibliographic coupling were found. The first study by Yuan et al. (2014a) focused on identifying recent subject areas and citation patterns of tourism research published between 2008 and 2012 in 10 leading tourism journals, including ATR, Current Issues in Tourism, IJTR, JTR, the Journal of Travel and Tourism Marketing, JST, the Scandinavian Journal of Hospitality and Tourism, Tourism Economics, Tourism Geographies, and TM. By assessing full-length articles, they illustrated 12 subject areas with 40 subtopics. Additionally, they presented the number of articles by topic and year, topic distribution for each journal, the geographic distribution of topics, and most cited documents by subject area. The second study was also by Yuan et al. (2014b) and identified tourism subfields by clustering journals via bibliographic coupling analysis on the bibliographic data of 37 journals in the hospitality, leisure, sport, and tourism category from 2008 and 2012. They identified five tourism subfields: tourism, hospitality, sports psychology, the sociology of leisure and sports, and sport economy.

Studies Conducted via Co-Authorship Analysis 
Three studies employed co-authorship network analysis. Hu and Racherla (2008) visualized a social network of the hospitality research domain via co-authorship data obtained from articles published in leading hospitality-focused journals (IJHM, CHQ, JHTR, and IJCHM) between 2001 and 2005. They showed the productivity of authors via power law and mapped the collaboration with a core-periphery, cohesive network, and contextual view of collaboration via Pajek. On the other hand, they ranked research streams, such as marketing and sales, consumer behavior, finance and accounting, human resources, and information technology, based on the density of each cohesive subnetwork. Racherla and $\mathrm{Hu}$ (2010) vetted the social structure of tourism research on articles published between 1996 and 2005 in three top tourism journals, including ATR, $J T R$, and TM. By dividing this period into two groups, they were able to visualize total tourism researchers, a global view of collaboration based on research streams, and a contextual view of the marketing group's collaborations with other research streams. In addition to this visualization, they presented a ranking of authors by centrality metrics, including degree, closeness, and "betweenness," and groups classified by the number of collaborations.

Ye et al. (2013) investigated critical scholars in tourism research collaborations and demonstrated the collaboration strategies of researchers from extroversive and introversive collaboration approaches from articles in three tourism (ATR, JTR, and TM) and three hospitality $(C H Q, I J H M$, and JHTR) journals between 1991 and 2010. They highlighted the notion that the tourism collaboration network is a small world reflecting the characteristics of real social networks and gauged its productivity by utilizing power law. Additionally, they showed changes in the network's structural features over five 
subperiods via UCINET. They ranked the authors based on centrality metrics, including degree, Bonancich power index, and betweenness.

\section{Studies Conducted via Co-Word Analysis}

There was only one study conducted (Ying and Xiao, 2012) via co-word analysis on dissertation subjects extracted from ProQuest Dissertations and the Theses-Full Text database (1994-2008). They employed a longitudinal examination utilizing three-year periods via UNICET, multidimensional analysis, and correspondence analysis. They identified 21 subjects as subdomains in the field and discussed the relationship between these subject areas and doctoral program distributions in tourism research. Additionally, and out of the scope of this current study's sample, several other studies have conducted relational studies in the tourism field (Benckendorff, 2009; Garcia-Lillo, Ubeda-Garcia, \& Marco-Lajara, 2016; Ozel \& Kozak, 2012).

\section{CONCLUSIONS, RECOMMENDATIONS AND FUTURE RESEARCH}

This study has sought to evaluate the progress of bibliometric studies in the tourism field. Data was gathered from nine leading tourism journals (indexed within the SSCI category) between 1988 and 2015. The study findings offer clear theoretical and practical implications by addressing the progress of bibliometric studies in tourism and also discussing the role of entities (individuals, groups, and institutions) in the field.

\section{Research implications of bibliometric structures in tourism}

The study findings highlight that there is a remarkable increase in bibliometric studies conducted via systematic review. However, the studies that employed relational bibliometric methods are rare. Although during the past 40 years, there has been a considerable increase in the number of papers published in tourism journals, and a 
considerable research community in the tourism field which is vibrant and exciting (Cheng et al., 2011; Hall, 2011; McKercher, 2008; McKercher \& Tung, 2015), relational bibliometric methods, particularly, have not been adapted promptly or have been lagging in the tourism literature showing interdisciplinary and transdisciplinary characteristics (Park \& Jang, 2014, Tribe, 2000; 2004; 2010). Therefore, particular discursive bibliometric structures in the tourism field are not enough to reveal unknown patterns in the evolution of the knowledge domain, collaborations, and contextual progress (McKercher \& Tung, 2015). To enrich the debates of the epistemological and ontological structure of knowledge creation in the field and make stronger theoretical advances, more research studies conducting relational bibliometric studies are needed.

The sampling process has a critical role for running bibliometric methods and increasing validity and reliability of these research studies. There are two ways to extract the data needed for bibliometric analysis. While one of them uses databases to extract data automatically, the other way requires researchers to find data manually by creating their related sample. However, researchers generally prefer the first way since latter involves arduous work to find and enter the data into a spreadsheet or related statistical programs. The current study results demonstrate that the samples of bibliometric studies have been formed from articles mainly indexed by SSCI or Scopus, or published in leading journals highly cited in the literature. These sampling preferences can create a few challenges to illuminating the knowledge domain of the field or contributing to theory development and test. First, these databases or leading journals may not fully represent the whole field, thus capturing only one part of the big picture. Given this, bibliometric studies should not only focus on leading journals but also other journals in the field as well as textbooks and other publications. However, researchers may not always be encouraged to delve into a piece of the big picture due to 
the "economization of research quality and knowledge production" (Hall, 2011: 25) and the importance of where one publishes rather than what one publishes (Hall, 2011). Second, networks constituted from institutions, policy makers, publishers, editors, or reviewers may impose guidelines regarding how researchers should create a sample of bibliometric studies. This is problematic because it suggests that in order to publish in a top-tier journal, researchers may have to abide by the bibliometric study guidelines that the top-tier journals impose in order to ensure that the journal remains top-tier. Therefore, we may say that bibliometrics are used to endorse publishers or journals to survive in the competitive environment generated by the commercialized or politicized academic publishing industry (Hall, 2011). On the other hand, since this situation generates its own small academic community by ignoring other possible samples (like journals not indexed in popular databases or local research published in local journals) studies related to bibliometric methods will be unable underwhelmed to assess or monitor the progress of the field from epistemological, ontological, and practical perspectives.

A longitudinal comparison of such maps informs us about the changes occurring in the social construction of the field and the evolving consensus, or lack thereof, about the domain of the field (Nerur et al., 2008). According to the findings of this study, applying a longitudinal approach is rare. Therefore, this generates barriers that prevent unknown patterns and changes among patterns in the field and the relationship between tourism and other disciplines to emerge.

The results of this current study reveal that researchers in the tourism field have mainly employed novel methods in the review studies. Such studies can be enriched further with relational bibliometric studies by developing more specific and comprehensive research questions. In this respect, the knowledge domain of 
subdisciplines can be further built systematically and analytically. However, current advances in the bibliometric field should be introduced to retrieve the data from databases, to lead social network analysis, and to map the structures of themes. Further, as a starting point, this study provides researchers with a broad insight into the unique research questions pertaining to the tourism field below:

- How have the subjects, research methods, samples, and utilized statistical techniques evolved over time in academic journal papers, conference proceedings, master's theses and doctoral dissertations?

- Which institutions have made the most contributions?

- How has the research changed over time and in which journal categories?

- How have research methodologies evolved over time in the tourism field?

- Are there any differences between methodologies employed in tourism and other disciplines?

- What kinds of methodological differences appear among countries and regions?

- What are the academic foundations in the tourism literature?

- How have the academic foundations of the tourism field evolved over time?

- What are the subfields of tourism? Have these subfields changed over time?

- What is the relationship between a co-authorship network and performance and quality of the papers? How do co-authorship networks influence the performance of researchers?

- What are the research groups in the fields? How have these research groups evolved over time?

- What are the conceptual structures of the tourism field? How have these structures evolved over time?

Recommendations: It is commonly accepted that tourism is an applied field. Given this, many scholars may strive to recommend new approaches and practices for practitioners rather than researchers. However, to promote the field and strengthen its academic foundation, researchers need to know the progress and evolution in the field. To regiment and direct the regular scholarly discussions on the evolution of all the dimensions of the fields, one may discuss the necessity of establishing a subfield 
(relying on bibliometric, informatics, or scientometrics) in tourism to foster both academic/theoretical and applied recommendations/techniques. Scholars in different career phases can be encouraged to support and undertake enhanced bibliometric studies by less susceptibility to publication-related pressures. Since scholars' research programs have these topics, doctoral programs should include bibliometric studies. Doctoral seminars focusing on bibliometric methods should be organized. Space for bibliometric studies may be created by top-tier journals with guidelines providing reviewers with more clarity to assess studies conducted via bibliometric methods. Academic institutions in our field should value bibliometric studies and recognize and reward researchers with a bibliometric research record with tenure and promotion opportunities or advancemects. Specific sessions or workshops can be organized at leading conferences to educate attendees about the value and importance of bibliometric studies and disseminate a culture of bibliometric approaches.

\section{Improving bibliometric studies}

As noted above, bibliometric is accepted as an interdisciplinary research field to extend all scientific fields based on scientific information and science policy (Glanzel, 2003). However, according to Glanzel (2003, p. 5): "It is a common misbelief that bibliometrics is nothing else but publication and citation based gauging of scientific performance or compiling of cleaned-up bibliographies on research domains extended by citation data. In fact, scientometrics is a multifaceted endeavor encompassing subareas such as structural, dynamic, evaluative and predictive scientometrics." Since bibliometric studies highlight the unknown patterns in fields or disciplines, these studies help researchers develop theories or test hypothesis. Hence, these structural, dynamic, evaluative, and predictive models can be skillfully applied in the evaluation and prediction of a field. 
The field of bibliometrics helps researchers identify publication activities, citation impact, scientific collaboration, and co-occurrences including co-word, co-heading, coauthor, bibliographic coupling with latent semantic indexing (Glanzel \& Thijs, 2012), and topic modeling (Blei, 2012). All methods are applicable for the tourism field to develop theories and testing. In this study, study results show that the usage of statistical package programs pertaining to relational methods is low. Therefore, the main problem is many researchers outside the bibliometrics field such as tourism do not know how they can employ these bibliometric methods and use bibliometric technologies (Glanzel, 2003) in their fields (Zupic \& Čater, 2015). Thus, it may be a particular problem to alter the way (or force progress in the way) bibliometric studies are conducted in the field of tourism. Hence, since the impacts of bibliometric studies may not be clearly understood to develop theories or testable predictions in the field, these methods may not be used enough for theory development and testing.

Recommendations. Bibliometric studies can contribute to theory development and testing in tourism by providing heuristic power (Yadav, 2010), via evaluation of current theories and methodologies. It can be recommended that to create a strong culture of bibliometric studies in the tourism field, the main action would be to develop strategies to break misbelief about bibliometrics by inviting bibliometricians to introduce and teach applications of the methodology of bibliometrics to tourism scholars. Collaboration opportunities can be provided with flagship schools focusing on bibliometrics as a research field. Tourism scholars should be encouraged to involve themselves in workshops held by bibliometricians at conferences.

\section{Potential challenges and barriers to bibliometric studies}

There are a few challenges and barriers to applying bibliometrics in the tourism field (see Hicks, 2004). First is the availability to resources. Bibliometric studies in 
tourism generally used SSCI or Scopus databases to extract bibliographic data since the other databases do not allow this kind of data collecting. Moreover, tourism literature is fragmented. Second is the type of sources used to collect the data. Bibliometric studies in tourism are generally conducted via article-based bibliometric methods since SSCI or Scopus only cover journals. Thus, researchers ignore books, book chapters, monographs, conference proceedings, etc. to assess the evolution of the field. Third is that there can be typos and errors in bibliographic data in the related databases. These typos and errors can impact the reliability of bibliometric analysis. Fourth is the omission of local research outputs. Many bibliometric studies focus on articles in English since the databases mainly consider articles written in English. Last is the scope of the samples formed for bibliometric analysis. This study shows that the samples of these studies include leading tourism journals. However, there may be other venues publishing articles that relate to tourism. Because of these biases, bibliometric outputs may be incomplete, unable to show a whole picture of the field. To increase reliability and validity of bibliometric studies in tourism the impact of these barriers should be considered and overcome where possible.

Recommendations. Tourism has a respectable academic community both internationally and locally around the world. Hence, this community should behave as a proactive player to enhance bibliometric studies in the field rather than as passive player watching and following the developments. Each discipline or field has their own characteristics. Given this, institutions or organizations may create their own bibliographic database and make them available online. To seek local research outputs written in non-English speaking countries, project groups can be established. Flagship journals should encourage researchers to search for patterns or evolutions in local outputs related to tourism. 


\section{Who benefits the most by new bibliometric methods}

As seen from interferences no one loses in the long term when bibliometric studies, with new bibliometric methods are conducted in the tourism literature. Initially, academic journals, publishers, organizations, institutions, or even authors may worry about losing their reputations or competitive edges. However, when new bibliometric methods are applied comprehensively, minimizing the aforementioned deficiencies, new patterns and opportunities will be unveiled for researchers by (re)inventing academic foundations of the field via quantitative methods rather than just qualitative reviews. Therefore, all stakeholders of the field will win in the long run by creating the culture and support for bibliometric studies in tourism. Additionally, tourism studies are industry based and can offer industry managers benefits to formulate and implement strategies and explore solutions for their problems. Bibliometric studies can provide helpful and timely information for researchers and managers. Therefore, scholars, managers, government officials, and consultants in the tourism field can benefit from the outcomes of such bibliometric studies.

\section{Politics and future of bibliometric research}

Since bibliometric studies generate new research agendas and directions for disciplines and/or fields, researchers can identify gaps in literature and practice. The findings of the bibliometric analysis in tourism can highlight the relationship between tourism and other disciplines or fields. Thus, new politics may be developed to enrich these relationships. Additionally, these studies are useful for policy makers and senior administrators who work at universities, government agencies, and research funding organizations when making policy decisions and allocating resources. Therefore, bibliometric studies are always needed at any maturity level of fields or disciplines. 


\section{LIMITATIONS AND FUTURE RESEARCH}

Similar to other studies, this study has its own limitations. First, the sample of the paper included only nine leading tourism journals. It is possible that there may be more bibliometric studies published in other tourism related journals or in journals in other fields. It is suggested that future studies should include a larger sample of journals. Second, as Hall (2011) stated, bibliometric analysis can be applied to any bibliometric unit, and it is not limited to studies of journal citations. However, in this current study, the sample included only articles published in nine tourism journals. Future studies may consider conference proceedings, books, and doctoral dissertations. Finally, bias might appear when the review studies are classified, since some papers cover two or more groups. In future studies, multiple authors may collectively classify these studies.

There are several other avenues for future studies. First, future studies can focus on a systematic review to identify contributors, such as authors, institutions, and countries. Second, the quality of bibliometric studies may be investigated by developing scales measuring the quality of research. Third, the performance of the bibliometric studies by using citation and/or co-citation impacts can be measured to gain more understanding in the field. Fourth, collaboration and the social network in bibliometric studies should be mapped and/or visualized. Fifth, the growth of the studies and productivity of researchers working in these fields of studies should be discussed in relation to research morals, values, economics, well-being etc. Sixth, bibliometric analysis of bibliometric studies in tourism in developed and developing countries should be sought. Seventh, future studies should look at how methodological processes have been utilized in bibliometric studies. Finally, future studies may compare bibliometric studies in the tourism field with bibliometric studies in other fields or disciplines. 


\section{REFERENCES}

References marked with an asterisk indicate studies that were included in the sample of the study. Also many of them were used in literature review of the study.

Acedo, F. J., Barroso, C., Casanueva, C., \& Galan, J. L. (2006). Co-Authorship in management and organizational studies: an empirical and network analysis. Journal of Management Studies 43(5), 957-983.

Aguinis, H., \& Glavas, A. (2012). What we know and don't know about corporate social responsibility a review and research agenda. Journal of Management, 38(4), 932-968.

*Anderson, C. K., \& Xie, X. (2010). Improving hospitality industry sales twenty-five years of revenue management. Cornell Hospitality Quarterly, 51(1), 53-67.

*Aragon-Correa, J. A., Martin-Tapia, I., \& de la Torre-Ruiz, J. (2015). Sustainability issues and hospitality and tourism firms' strategies Analytical review and future directions. International Journal of Contemporary Hospitality Management, 27(3), 498-522.

*Ardoin, N. M., Wheaton, M., Bowers, A. W., Hunt, C. A., \& Durham, W. H. (2015). Naturebased tourism's impact on environmental knowledge, attitudes, and behavior: a review and analysis of the literature and potential future research. Journal of Sustainable Tourism, 23(6), 838-858.

*Ashworth, G., \& Page, S. J. (2011). Urban tourism research: Recent progress and current paradoxes. Tourism Management, 32, 1-15.

*Athiyaman, A. (1995). The interface of tourism and strategy: an analysis. Tourism Management, 16(6), 447-453.

*Azzopardi, E., \& Nash, R. (2013). A critical evaluation of importance- performance analysis. Tourism Management, 35, 222-233.

*Ballantyne, R., Packer, J., \& Axelsen, M. (2009). Trend in tourism research. Annals of Tourism Research, 36(1), 149-152.

*Baloglu, S., \& Assante, L. M. (1999). A content analysis of subject areas and research methods used in five hospitality management journals. Journal of Hospitality \& Tourism Research, 23(1), 53-70.

Bao, J. (2002). Tourism geography as the subject of doctoral dissertations in China, 1989e2000. Tourism Geographies, 4, 148-152.

Barrios, M., Borrego, A., Vilaginés, A., Ollé, C., \& Somoza, M. (2008). A bibliometric study of psychological research on tourism. Scientometrics, 77(3): 453-467.

Belhassen, Y., \& Caton, K. (2009). Advancing understandings: A linguistic approach to tourism epistemology. Annals of Tourism Research, 36(2), 335-352.

Benckendorff, P. (2009). Themes and trends in Australian and New Zealand tourism research: A social network analysis of citations in two leading journals (1994-2007). Journal of Hospitality and Tourism Management, 16, 1-15.

*Benckendorff, P., \& Zehrer, A. (2013). A netwrok analysis of tourism research. Annals of Tourism Research, 43, 121-149.

Blei, D. M. (2012). Probabilistic topic models. Communications of the ACM, 55(4), 77-84.

*Bloisi, W., \& Hoel, H. (2008). Abusive work practices and bullying among chefs: A review of the literature. International Journal of Hospitality Management, 27, 649-656.

*Blum, S. C. (1997). Current concerns: a thematic analysis of recent hospitality industry issues. International Journal of Contemporary Hospitality Management, 9(7), 350-361.

Boyack, K., Klavans, R., \& Börner, K. (2005). Mapping the backbone of science. Scientometrics, 64 (3), 351-374.

*Bowen, J. T., \& Sparks, B. A. (1998). Hospitality marketing research: a content analysis and implications for future research. International Journal of Hospitality Management, 17, 125-144.

Börner, K., Chen, C., \& Boyack, K. W. (2003). Visualizing knowledge domains. Annual review of information science and technology, 37(1), 179-255. 
Broadus, R. (1987). Toward a definition of "bibliometric". Scientometrics, 12(5-6), 373-379.

*Buckley, R. (2012). Sustainable tourism: research and reality. Annals of Tourism Research, 39(2), 528-546.

*Buhalis, D., \& Law, R. (2008). Progress in information technology and tourism management: 20 years on and 10 years after the Internet- The state of eTourism research. Tourism Management, 29.609-623.

*Cantallops, A. S., \& Salvi, F. (2014). New consumer behavior: A review of research on eWOM and hotels. International Journal of Hospitality Management, 36, 41-51.

*Carter, R. W., Baxter, G. S., \& Hockings, M. (2001). Resource Management in Tourism Research: A new Direction? Journal of Sustainable Tourism, 9(4), 265-280.

*Carter, R. W., Thok, S., O'Rourke, V., \& Pearce, T. (2015). Sustainable tourism and its use as a development strategy in Cambodia: a systematic literature review. Journal of Sustainable Tourism, 23(5), 797-818.

Casillas, J., \& Acedo, F. (2007). Evolution of the intellectual structure of family business literature: A bibliometric study of FBR. Family Business Review, 20(2), 141-162.

*Castro-Nuno, M., Molina-Toucedo, J. A., \& Pablo-Romero, M. P. (2013). Tourism and GDP: a meta-analysis of panel data studies. Journal of Travel Research, 52(6), 745-758.

Chan, E. S. W., \& Hsu, C. H. C. (2016). Environmental management research in hospitality. International Journal of Contemporary Hospitality Management, 28(5), pp. -

*Chen, C., \& Petrick, J. F. (2013). Health and Wellness Benefits of Travel Experiences: A Literature Review. Journal of Travel Research, 52(6), 709-719.

*Chen, R. X., Cheung, C., \& Law, R. (2012). A review of the literature on culture in hotel management research: what is the future?. International Journal of Hospitality Management, 31(1), 52-65.

*Cheng, C., Li, X., Petrick, J. F., \& O'Leary, J. T. (2011). An examination of tourism journal development. Tourism Management, 32, 53-61.

*Chon, K. S., Evans, M. R., \& Sutherlin, D. (1989). Trends in hospitality management literature: a content analysis. Journal of Hospitality \& Tourism Research, 13(3), 483491.

*Chuang, T. C., Liu, J. S., Lu, L. Y. Y., \& Lee, Y. (2014). The main paths of medical tourism: From transplantation to beautification. Tourism Management, 45, 49-58.

Cobo, M. J., López-Herrera, A. G., Herrera-Viedma, E., \& Herrera, F. (2011). Science mapping software tools: Review, analysis, and cooperative study among tools. Journal of the American Society for Information Science and Technology, 62(7), 1382-1402.

*Cohen, E., \& Cohen, S. A. (2012). Current sociological theories and issues in tourism. Annals of Tourism Research, 39(4), 2177-2202.

*Confente, I. (2014). Twenty-Five Years of Word-of-Mouth studies: A critical review of Tourism research. International Journal of Tourism Research, DOI: 10.1002/jtr.2029.

*Connell, J. (2012). Film tourism - Evolution, progress and prospects. Tourism Management, $33,1007-1029$.

Coulter, N., Monarch, I. \& Konda, S. (1998). Software engineering as seen through its research literature: A study in co-word analysis. Journal of the American Society for Information Science, 49(13), 1206-1223.

*Crawford-Welch, S., \& McCleary, K. W. (1992). An identification of the subject areas and research techniques used in five hospitality-related journals. International Journal of Hospitality Management, 11(2), 155-167.

*Crick, A. P., \& Spencer, A. (2011). Hospitality quality: new directions and new challenges. International Journal of Contemporary Hospitality Management, 23(4), 463-478.

*Crouch, G. I., \& Perdue, R. R. (2015). The Disciplinary Foundations of Tourism Research: 1980-2010. Journal of Travel Research, 54(5), 563-577. 
*Davidson, M. C. G., McPhail, R., \& Barry, S. (2011). Hospitality HRM: past, present and future. International Journal of Contemporary Hospitality Management, 23(4), 498516.

*Deery, M., Jago, L., \& Fredline, L. (2012). Rethinking social impacts of tourism research: a new research agenda. Tourism Management, 33, 64-73.

*Deery, M., \& Jago, L. (2015). Revisiting talent management, work-life balance and retention strategies. International Journal of Contemporary Hospitality Management, 27(3), 453-472.

*Dev, C. S., Buschman, J. D., \& Bowen, J. T. (2010). Hospitality marketing: A retrospective analysis (1960-2010) and predictions (2010-2020). Cornell Hospitality Quarterly, 51(4), 459-469.

Diodato, V. (1994). Dictionary of Bibliometric. Haworth Press, Binghamton.

*Dolnicar, S., \& Ring, A. (2014). Tourism marketing research: Past, present and future. Annals of Tourism Research, 47, 31-47.

*Donohoe, H., Pennington-Gray, L., \& Omodior, O. (2015). Lyme disease: Current issues, implications, and recommendations from tourism management. Tourism Management, 46, 408-418.

*Dredge, D., \& Jamal, T. (2015). Progress in tourism planning and policy: A post-structural perspective on knowledge production. Tourism Management, 51, 285-297.

*Durko, A. M., \& Petrick, J. F. (2013). Familiy and Relationship Benefits of Travel Experiences: A Literature Review. Journal of Travel Research, 52(6), 720-730.

*Eccles, G., \& Costa, J. (1996). Perspectives on tourism development. International Journal of Contemporary Hospitality Management, 8(7), 44-51.

*Edwards, D., Griffin, T., \& Hayllar, B. (2008). Urban Tourism Research Developing an agenda. Annals of Tourism Research, 35(4), 1032-1052.

Enver, S., \& Kozak, N. (2014). Bibliometric analysis of tourism and hospitality related articles published in Turkey. Anatolia: An International Journal of Tourism and Hospitality Research, 25, 61-80.

Fagerberg, J., Fosaas, M., Sapprasert, K., 2012. Innovation: exploring the knowledge base. Research Policy 41 (7), 1132-1153.

Fagerberg, J., Verspagen, B., 2009. Innovation studies - the emerging structure of a new scientific field. Research Policy 38, 218-233.

*Feinstein, A. H., \& Parks, S. J. (2002). The use of simulation in hospitality as an analytic tool and instructional system: a review of the literature.Journal of Hospitality \& Tourism Research, 26(4), 396-421.

*Figueroa-Domecq, C., Pritchard, A., Segovia-Perez, M., Morgan, N., \& Villace-Molinero, T. (2015). Annals of Tourism Research, 52, 87-103.

*Frew, A. J. (). Information and Communications Technology Research in the Travel and Tourism Domain: Perspective and Direction. Journal of Travel Research, 39, 136-145.

Fong, L. H. N., Law, R., Tang, C. M. F., \& Yap, M. H. T. (2016). Experimental research in hospitality and tourism: a critical review. International Journal of Contemporary Hospitality Management, 28(2), $246-266$.

*Galani-Moutafi, V. (2004). Tourism research on Greece a crtical overview. Annals of Tourism Research, 31(1), 157-179.

Garcia-Lillo, F., Ubeda-Garcia, M., \& Marco-Lajara, B. (2016). The intellectual structure of research in hospitality management: A literature review using bibliometric methods of the journal International Journal of Hospitality Management. International Journal of Hospitality Management, 52, 121-130.

Gartner, W. B., Davidsson, P., \& Zahra, S. A. (2006). Are you talking to me? The nature of community in entrepreneurship scholarship. Entrepreneurship Theory and Practice, 30(3), 321-331. 
*Getz, D. (2008). Event tourism: Definition, evolution, and research. Tourism Management, 29, 403-428.

Glanzel, W. (2003). Bibliometric as a research field A course on theory and application of bibliometric indicators, Course Handouts, http://nsdl.niscair.res.in/jspui/bitstream/123456789/968/1/Bib_Module_KUL.pdf (1.20.2016).

Glanzel, W., \& Thijs, B. (2012). Using "core documents" for detecting and labelling new emerging topics. Scientometrics, 91(2), 399-416.

Gomezeli, D. O. (2016). A systematic review of research on innovation in hospitality and tourism", International Journal of Contemporary Hospitality Management, 28(3), 516 -558 .

Gregory, A. M. \& Weinland, J. (2016). Timeshare research: a synthesis of forty years of publications", International Journal of Contemporary Hospitality Management, 28(3), $438-470$.

*Gretzel, U. (2011). Intelligent systems in tourism A social science perspective. Annals of Tourism Research, 38(3), 757-779.

*Guerrier, Y., \& Deery, M. (1998). Research in hospitality human resource management and organizational behaviour. International Journal of Hospitality Management, 17, 145160.

*Guillet, B. D., \& Mohammed, I. (2015). Revenue management research in hospitality and tourism: a critical review of current literature and suggestions for future research. International Journal of Contemporary Hospitality Management, 27(4), 526-560.

*Gummesson, E. (2014). Productivity, quality and relationship marketing in service operations: A revisit in a new service paradigm. International Journal of Contemporary Hospitality Management, 26(5), 656-662.

*Gursoy, D., Chen, J. S., \& Chi, C. G. (2014). Theoretical examination of destination loyalty formation. International Journal of Contemporary Hospitality Management, 26(5), 809-827.

Hall, C. M. (1991). Tourism as the subject of post-graduate dissertations in Australia. Annals of Tourism Research, 18, 520-523.

*Hall, C. M. \& Page, S. J. (2009). Progress in Tourism Management: From the geography of tourism- a review. Tourism Management, 30, 3-16.

*Hall, C. M., (2011). Publish and perish? Bibliometric analysis, journal ranking and the assessment of research quality in tourism. Tourism Management, 32, 16-27.

*Hallin, C. A., \& Marnburg, E. (2008). Knowledge management in the hospitality industry: A review of emprical research. Tourism Management, 29, 366-381.

*Harrington, R. J., \& Ottenbacher, M. C. (2011). Strategic management: an analysis of its representation and focus in recent hospitality research. International Journal of Comtemporary Hospitality Management, 23(4), 439-462.

*Harrington, R. J., Chathoth, P. K., Ottenbacher, M., \& Altinay, L. (2014). Strategic management research in hospitality and tourism: past, present and future. International Journal of Comtemporary Hospitality Management, 26(5), 778-808.

*Harris, P. J., \& Brown, J. B. (1998). Research and development in hospitality accounting and financial management. International Journal of Hospitality Management, 17, 161-181.

*Hesford, J. W., \& Potter, G. (2010). Accounting research in the Cornell Quarterly: A review with suggestions for future research. Cornell Hospitality Quarterly.

Hicks, D. (1999). The difficulty of achieving full coverage of international social science literature and the bibliometric consequences. Scientometrics, 44(2), 193-215.

Hicks, D. (2004). The four literatures of social science. In H. F. Moed, W. Glänzel, \& U. Schmoch (Eds.), Handbook of quantitative science and technology research: The use of publication and patent statistics in studies of S\&T systems (pp. 473e496). 
*Hinch, T. D., \& Higham, J. E. S. (2001). Sport tourism: a framework for research. International Journal of Tourism Research, 3, 45-58.

*Hing, N. (1997). A review of hospitality research in the Asia Pacific region 1989-1996: a thematic perspective. International Journal of Contemporary Hospitality Management, 9(7), 241-253.

*Hing, N. (1997). Contemporary tourism issues in Asia Pacific journals 1989-1996: a thematic perspective. International Journal of Contemporary Hospitality Management, 9(7), 254-269.

*Hjalager, A. (2010). A review of innovation research in tourism. Tourism Management, 31, 112.

*Howey, R. M., Savage, K. S., Verbeeten, M. J., Van Hoof, H. B. (1999). Tourism and hospitality research journals: cross-citations among research communities. Tourism Management, 20, 133-139.

*Hu, C. (1996). Diverse developments in travel and tourism marketing: a thematic approach. International Journal of Contemporary Hospitality Management, 8(7), 33-43.

*Hu, C., \& Racherla, P. (2008). Visual representation of knowledge networks: A social network analysis of hospitality research domain. International Journal of Hospitality Management, 27, 302-312.

*Hung, K., \& Law, R. (2011). An overview of internet-based surveys in hospitality and tourism journals. Tourism Management, 32, 717-724.

*Ip, C., Law, R., \& Lee, H. A. (2011). A review of website evaluation studies in the tourism and hospitality fileds from 1996 to 2009. International Journal of Tourism Research, 13, 234-265.

*Ip, C., Leung, R., \& Law, R. (2011). Progress and development of information and communication technologies in hospitality. International Journal of Contemporary Hospitality Management, 23(4), 533-551.

*Jamal, T., Smith, B., \& Watson, E. (2008). Ranking, rating, and scoring of tourism journals: Interdisciplinary challenges and innovations. Tourism Management, 29, 66-78.

*Jang, S., \& Park, K. (2011). Hospitality finance research during recent two decades: Subjects, methodologies, and citations. International Journal of Contemporary Hospitality Management, 23(4), 479-497.

Jobber, David and Paul Simpson (1988), "A Citation Analysis of Selected Marketing Journals," International Journal of Research in Marketing, 5 (2), 137-142.

*Jogaratnam, G., Chon, K., McCleary, K., Mena, M., \& Yoo, J. (2005). An analysis of institutional contributors to three major academic tourism journals: 1992-2001. Tourism Management, 26, 641-648.

*Jogaratnam, G., McCleary, K. W., Mena, M. M., \& Yoo, J. J. E. (2005). An analysis of hospitality and tourism research: Institutional contributions. Journal of Hospitality \& Tourism Research, 29(3), 356-371.

*Johns, N., \& Pine, R. (2002). Consumer behaviour in the food service industry: a review. International Journal of Hospitality Management, 21, 119-134.

*Jones, P., \& Lockwood, A. (1998). Operations management research in the hospitality industry. International Journal of Hospitality Management, 17, 183-202.

*Kandampully, J., Keating, B. W., Kim, B. P., Mattila, A. S., \& Solnet, D. (2014). Service Research in the Hospitality Literature Insights from a Systematic Review. Cornell Hospitality Quarterly, 55(3), 287-299.

*Kandampully, J., Zhang, T., \& Bilgihan, A. (2015). Customer loyalty: a review and future directions with a special focus on the hospitality industry. International Journal of Contemporary Hospitality Management, 27(3), 379-414.

*Kasimati, E. (2003). Economics aspects and summer olympics: a review of related research. International Journal of Tourism Research, 5, 433-444. 
Katz, J. S., \& Martin, B. R. (1997). What is research collaboration?. Research policy, 26(1), 118.

Kim, J., \& McMillan, S. J. (2008). Evaluation of internet advertising research: A bibliometric analysis of citations from key sources. Journal of Advertising, 37(1), 99-112.

*Kim, M. G., Wang, C., \& Mattila, A. S. (2010). The relationship between consumer complaining behavior and service recovery an integrative review. International Journal of Comtemporary Hospitality Management, 22(7), 975-991.

*Kim, Y., Savage, K. S., Howey, R. M., \& Van Hoof, H. B. (2009). Academic foundations for hospitality and tourism research: A reexamination of citations. Tourism Management, 30, $752-758$.

*Kirk, D., \& Pine, R. (1998). Research in hospitality systems and technology. International Journal of Hospitality Management, 17, 203-217.

*Koenig-Lewis, N., \& Bischoff, E. E. (2005). Seasonality research: The state of the art. International Journal of Tourism Research, 7, 201-219.

*Kong, H., \& Cheung, C. (2009). Hotel development in China: a review of the English language literature. International Journal of Contemporary Hospitality Management, 21(3), 341355.

*Koseoglu, M. A., Sehitoglu, Y., \& Craft, J. (2015a). Academic foundations of hospitality management research with an emerging country focus: A citation and co-citation analysis. International Journal of Hospitality Management,45, 130-144.

Koseoglu, M. A., Sehitoglu, Y., \& Parnell, J. A. (2015b). A bibliometric analysis of scholarly work in leading tourism and hospitality journals: the case of Turkey. Anatolia: An International Journal of Tourism and Hospitality Research, 26(3), 359-371.

Koseoglu, M. A. (2016). Growth and structure of authorship and co-authorship network in the strategic management realm: evidence from Strategic Management Journal. BRQ Business Research Quarterly, 19, 153-170.

Koseoglu, M. A., Sehitoglu, Y., Ross, G. \& Parnell, J. A. (2016). The Evolution of Business Ethics Research in the Realm of Tourism and Hospitality: A Bibliometric Analysis. International Journal of Contemporary Hospitality Management, 28(8), 1598- 1621

*Kusluvan, S., Kusluvan, Z., Ilhan, I., \& Buyruk, L. (2010). The human dimension a review of human resources management issues in the tourism and hospitality industry. Cornell Hospitality Quarterly, 51(2), 171-214.

*Ladkin, A. (1999). Hotel general managers: A review of prominent research themes. International Journal of Tourism Research, 1, 167-193.

Laing, J. H., \& Weiler, B. (2008). Postgraduate tourism research in Australia: A trend analysis 1969e2005. In where the bloody hell are we?. In Proceedings of the eighteenth international research conference of the council for Australian University tourism and hospitality education (CAUTHE), Gold Coast, 11e14 February, 2008 Gold Coast: Griffith University.

Landström, H., Harirchi, G., \& Åström, F. (2012). Entrepreneurship: Exploring the knowledge base. Research Policy, 41(7), 1154-1181.

*Law, R., \& van der Veen, R. (2008). The popularity of prestigious hospitality journals: a Google Scholar approach. International Journal of Contemporary Hospitality Management, 20(2), 113-125.

*Law, R., Buhalis, D., \& Cobanoglu, C. (2014). Progress on information and communication technologies in hospitality and tourism. International Journal of Contemporary Hospitality Management, 26(5), 727-750.

*Law, R., Leung, D., \& Au, N. (2013). Progress and development of information technology in the hospitality industry evidence from Cornell Hospitality Quarterly. Cornell Hospitality Quarterly, 54(1), 10-24.

*Law, R., Leung, D., \& Cheung, C. (2012). A systematic review, analysis, and evaluation of research articles in the Cornell Hospitality Quarterly. Cornell Hospitality Quarterly, 53(4), 365-381. 
*Law, R., Leung, R., \& Buhalis, D. (2010). An analysis of academic leadership in hospitality and tourism journals. Journal of Hospitality \& Tourism Research.

*Law, R., Qi, S., \& Buhalis, D. (2010). Progress in tourism management: a review of website evaluation in tourism research. Tourism Management, 31, 297-313.

*Law, R., Wu, J., \& Liu, J. (2014). Progress in Chinese hotel research: A review of SSCI-listed journals. International Journal of Hospitality Management, 42, 144-154.

*Leask, A. (2010). Progress in visitor attraction research: Towards more effective management. Tourism Management, 31, 155-166.

*Lee, M. J., \& Back, K. (2005). A review of economic value drivers in convention and meeting management research. International Journal of Contemporary Hospitality Management, 17(5), 409-420.

Leydesdorff, L. \& Vaughan, L. (2006). Co-occurrence matrices and their applications in information science: Extending ACA to the Web environment. Journal of the American Society for Information Science and Technology 57(12), 1616-1628.

*Li, L. (2008). A review of entrepreneurship research published in the hospitality and tourism management journals. Tourism Management, 29, 1013-1022.

*Li, M. (2012). Cross-cultural tourist research: A meta-analysis. Journal of Hospitality \& Tourism Research, 1096348012442542.

*Lim, C. (1997). Review of international tourism demand models. Annals of Tourism Research, 24(4), 835-849.

*Line, N. D., \& Runyan, R. C. (2012). Hospitality marketing research: Recent trends and future directions. International Journal of Hospitality Management, 31(2), 477-488.

*Lu, J., \& Nepal, S. K. (2009). Sustainable tourism research: an analysis of papers published in the Journal of Sustainable Tourism. Journal of Sustainable Tourism, 17(1), 5-16.

Lu, K., \& Wolfram, D. (2012). Measuring author research relatedness: A comparison of word-based, topic-based, and author cocitation approaches. Journal of the American Society for Information Science and Technology, 63(10), 1973-1986.

*Lucas, R., \& Deery, M. (2004). Significant developments and emerging issues in human resource management. International Journal of Hospitality Management, 23, 459-472.

*Luthe, T., \& Wyss, R. (2014). Assessing and planning resilience in tourism. Tourism Management, 44, 161-163.

*Mason, P. (2000). Zoo tourism: The need for more research. Journal of Sustainable Tourism, $8(4), 333-339$.

*Mattila, A. S. (2004). Consumer behavior research in hospitality and tourism journals. International Journal of Hospitality Management, 23, 449-457.

Mayo, E. J., \& Jarvis, L. P. (1981). The psychology of leisure travel: Effective marketing and selling of travel services. Boston, Mass: CBI Pub. Co.

McBurney, M. K., \& Novak, P. L. (2002). What is bibliometric and why should you care?In: Proceedings of the Professional Communication Conference, pp. 108-114.

McCain,K.W. (1990). Mapping authors in intellectual space: a technical overview. Journal of American Society for Information Science. 41, 433-443.

*McKercher, B. (2008). A citation analysis of tourism scholars. Tourism Management, 29, 1226-1232.

*McKercher, B., \& Tung, V. (2015). Publishing in tourism and hospitality journals: Is the past a prelude to the future? Tourism Management, 50, 306-315.

McKercher, B., Law, R., \& Lam, T. (2006). Rating tourism and hospitality journals. Tourism Management, 27(6), 1235-1252.

Meho, L. I., \& Yang, K. (2007). Impact of data sources on citation counts and rankings of LIS faculty: Web of science versus scopus and google scholar. Journal of the American Society for Information Science and Technology, 58: 2105-2125. 
Meyer-Arendt, K. J. (2000). Commentary: tourism geography as the subject of north American doctoral dissertations and master's theses, 1951-98. Tourism Geographies, 2(2), 140156.

Meyer-Arendt, K. J., \& Justice, C. (2002). Tourism as the subject of North American doctoral dissertations, 1987e2000. Annals of Tourism Research, 29, 1171-1174.

*Mohammed, I., Guillet, B. D., \& Law, R. (2015). The contributions of economics to hospitality literature: A content analysis of hospitality and tourism journals. International Journal of Hospitality Management, 44, 99-110.

*Morosan, C., Bowen, J. T., \& Atwood, M. (2014). The evolution of marketing research. International Journal of Contemporary Hospitality Management, 26(5), 706-726.

*Morrison, A. (2002). Hospitality research: a pause for reflection. International Journal of Tourism Research, 4, 161-169.

*Morrison, A., Carlsen, J., \& Weber, P. (2010). Small Tourism Business Research Change and Evolution. International Journal of Tourism Research, 12, 739-749.

*Murphy, J., \& Law, R. (2008). Google scholar visibility and tourism journals. Annals of Tourism Research, 35(4), 1078-1082.

*Myung, E., McClaren, A., \& Li, L. (2012). Environmentally related research in scholarly hospitality journals: Current status and future opportunities.International Journal of Hospitality Management, 31(4), 1264-1275.

Nerur, S., Rasheed, A., \& Natarajan, V. (2008). The intellectual structure of the strategic management field: An author co-citation analysis. Strategic Management Journal, 29, 319-336.

Nerur, S., Rasheed, A.A., Pandey, A. 2015. Citation footprints on the sands of time: an analysis of idea migrations in strategic management. Strategic Management Journal, DOI: 10.1002/smj.2377.

Nerur, S., Rasheed, A.A., Pandey, A. 2015. Citation footprints on the sands of time: an analysis of idea migrations in strategic management. Strategic Management Journal, DOI: 10.1002/smj.2377.

*Nunkoo, R., Ramkissoon, H., \& Gursoy, D. (2013). Use of structural equation modeling in tourism research: past, present, and future. Journal of Travel Research, 52(6), 759-771.

*Nunkoo, R., Smith, S. L. J., \& Ramkissoon, H. (2013). Residents' attitudes to tourism: a longitudinal study of 140 articles from 1984 to 2010. Journal of Sustainable Tourism, 21(1), 5-24.

*O'Connor, P., \& Murphy, J. (2004). Research on information technology in the hospitality industry. International Journal of Hospitality Management, 23, 473-484.

*Oguztimur, S., \& Akturan, U. (2015). Synthesis of city branding literature (1988-2014) as a research domain. International Journal of Tourism Research, DOI: 10.1002/jtr.2054

*Oh, H., Kim, B., \& Shin, J. (2004). Hospitality and tourism marketing: recent developments in research and future directions. International Journal of Hospitality Management, 23, 425-447.

*Olsen, M. D. (2004). Literature in strategic management in the hospitality industry. International Journal of Hospitality Management, 23, 411-424.

*Olsen, M. D., \& Roper, A. (1998). Research in strategic management in the hospitality industry. International Journal of Hospitality Management, 17, 111-124.

*O'Neill, J. W., \& McGinley, S. (2014). Operations research from 1913 to 2013. International Journal of Contemporary Hospitality Management, 26(5), 663-678.

Ozel, C. H., \& Kozak, N. (2012). Bibliometric Profile of Tourism Marketing Literature from 2000 to 2010 and a Citation Analysis Study. Turk Kutuphaneciligi, 26(4), 715-733.

*Page, S. J. (2003). Evaluating research performance in tourism: the UK experience. Tourism Management, 24, 607-622.

Page, S. J. (2005). Academic ranking exercises: So they achieve anything meaningful? A personal view. Tourism Management, 26(5), 663-666. 
*Page, S. J. (2009). Current issue in tourism: the evolution of travel medicine research: a new research agenda for tourism? Tourism Management, 30, 149-157.

*Palmer, A. L., Sese, A., \& Montano, J. J. (2005). Tourism and Statistics Bibliometric Study 1998-2002. Annals of Tourism Research, 32(1), 167-178.

*Park, K., \& Jang, S. (2014). Hospitality finance and managerial accounting research: suggesting an interdisciplinary research agenda. International Journal of Contemporary Hospitality Management, 26(5), 757-777.

*Park, K., Phillips, W. J., Canter, D. D., \& Abbott, J. (2011). Hospitality and tourism research rankings by author, university, and country using six major journals: The first decade of the new millennium. Journal of Hospitality \& Tourism Research, 35,381-416.

Pearce, P. L. (1982). The social psychology of tourist behaviour (Vol. 3). Oxford, New York: Pergamon Press.

*Pearce, D. G. (2014). The internationalization of tourism research. Journal of Travel Research, 53(3), 267-280.

*Pearce, P. L., \& Packer, J. (2013). Minds on the move: new links from psychology to tourism. Annals of Tourism Research, 40, 386-411.

Pechlaner, H., Zehrer, A., \& Abfalter, D. (2002). How can scientific quality be assessed? An exploratory study of tourism and hospitality journals. Tourism - An International Interdisciplinary Journal, 50, 395-399.

*Pechlaner, H., Zehrer, A., Matzler, K., \& Abfalter, D. (2004). A ranking of international tourism and hospitality journals. Journal of Travel Research, 42, 328-332.

*Peng, B., Song, H., \& Crouch, G. I. (2014). A meta-analysis of international demand forecasting and implications for practice. Tourism Management, 45, 181-193.

*Peng, B., Song, H., Crouch, G. I., \& Witt, S. F. (2015). A meta-analysis of international tourism demand elasticities. Journal of Travel Research, 54(5), 611-633.

*Phillips, P., \& Moutinho, L. (2014). Critical review of strategic planning research in hospitality and tourism. Annals of Tourism Research, 48, 96-120.

*Pike, S. (2002). Destination image analysis- a review of 142 papers from 1973 to 2000. Tourism Management, 23, 541-549.

*Pike, S., \& Page, S. J. (2014). Destination marketing organizations and destination marketing: A narrative analysis of the literature. Tourism Management, 41, 202-227.

Pilkington, A., \& Chai, K. H. (2008). Research themes, concepts and relationships: A study of International Journal of Service Industry Management (1990-2005). International Journal of Service Industry Management, 19(1), 83-110.

Pilkington, A., \& Fitzgerald, R. (2006). Operations management themes, concepts and relationships: a forward retrospective of IJOPM. International Journal of Operations \& Production Management, 26(11), 1255-1275.

*Pittaway, L., Carmouche, R., \& Chell, E. (1998). The way forward: Leadership research in the hospitality industry. International Journal of Hospitality Management, 17, 407-426.

*Poria, Y., \& Timothy, D. J. (2014). Where are the children in tourism research? Annals of Tourism Research, 47, 77-95.

*Pullman, M., \& Rodgers, S. (2010). Capacity management for hospitality and tourism: A review of current approaches. International Journal of Hospitality Management, 29(1), 177-187.

*Racherla, P., \& Hu, C. (2010). A social network perspective of tourism research collaborations. Annals of Tourism Research, 37(4), 1012-1034.

Raghuram, S., Tuertscher, P., \& Garud, R. (2010). Research note-mapping the field of virtual work: A cocitation analysis. Information Systems Research, 21(4), 983-999.

Ramos-Rodriguez, A-R., Ruiz-Navarro, J. 2004. Changes in the intellectual structure of strategic management research: a bibliometric study of the Strategic Management Journal, 1980-2000. Strategic Management Journal, 25(10), 981-1004.

Rani, Y. S., \& Nagaraju, K. Webology: A Bibliometric Analysis. 
*Riley, M. (2007). Role interpretation during service encounters: a critical review of modern approaches to service quality management. International Journal of Hospitality Management, 26, 409-420.

*Ritchie, J. R. B., \& Hudson, S. (2009). Understanding and meeting the challenges of cinsumer/ tourist experience research. International Journal of Tourism Research, 11, 111-126.

*Ritchie, J. R. B., Tung, V. W. S., \& Ritchie, R. J. B. (2011). Tourism experience management research: Emergence, evolution and future firections. International Journal of Comtemporary Hospitality Management, 23(4), 419-438.

*Rivera, M. A., \& Pizam, A. (2015). Advances in hospitality research: "from Rodney Dangerfield to Aretha Franklin". International Journal of Contemporary Hospitality Management, 27(3), 362-378.

*Rivera, M. A., \& Upchurch, R. (2008). The role of research in the hospitality industry: A content analysis of the IJHM between 2000 and 2005. International Journal of Hospitality Management, 27, 632-640.

*Ro, H. (2012). Moderator and mediator effects in hospitality research.International Journal of Hospitality Management, 31(3), 952-961.

Ronda-Pupo, G.A., Guerras-Martín, L. Á. 2012. Dynamics of the evolution of the strategy concept 1962-2008: a co-word analysis. Strategic Management Journal, 33(2), 162188.

*Ryan, C. (2005). The ranking and rating of academics and journals in tourism research. Tourism Management, 26, 657-662.

*Sainaghi, R. (2010). Hotel performance: state of the art. International Journal of Comtemporary Hospitality Management, 22(7), 920-952.

Schmidgall, R., Woods, R. H., \& Hardigree, C. (2007). Hospitality's most influential scholars: Fifteen years of citation analyses (1989-2004). Journal of Hospitality and Tourism Education, 19, 32-43.

Schmidt, J. C. (2008). Towards a philosophy of interdisciplinarity: An attempt to provide a classification and clarification. Poiesis \& Praxis: International Journal of Technology Assessment and Ethics of Science, 5, 53-69.

Sen gupta, I.N. (1988). Bibliometric Research, growth of biomedical literature, Calcutta: SBA publishing

* Sharpley, R. (2014). Host perceptions of tourism: A review of the research. Tourism Management, 42, 37-49.

* Shaw, G., \& Williams, A. (2009). Knowledge transfer and management in tourism organisations: An emerging research agenda. Tourism Management, 30, 325-335.

*Sheldon, P. J. (1991). An authorship analysis of tourism research. Annals of Tourism Research, 18, 473-484.

* Sigala, M. (2013). Customer involvement in sustainable supply chain management a research framework and implications in tourism. Cornell Hospitality Quarterly, 1938965513504030.

*Silva, J. A., Rodrigues, P. M. M., Mendes, J., \& Pereira, L. N. (2010). A tourism research agenda for Portugal. International Journal of Tourism Research, 12, 90-101.

*Singh, N., Hu, C., \& Roehl, W. S. (2007). Text mining a decade of progress in hospitality human resource management research: identifying emerging thematic development. International Journal of Hospitality Management, 26, 131-147.

Small, H. (1973). Co-citation in the scientific literature: A new measure of the relationship between two documents. Journal of the American Society for information Science, 24(4), 265-269.

*Song, H., \& Li, G. (2008). Tourism demand modelling and forecasting- A review of recent research. Tourism Management, 29, 203-220.

*Song, H., Dwyer, L., Li, G., \& Cao, Z. (2012). Tourism economics reserch: a review and assessment. Annals of Tourism Research, 39(3), 1653-1682. 
*Sourouklis, C., \& Tsagdis, D. (2013). Workforce diversity and hotel performance: A systematic review and synthesis of the international empirical evidence. International Journal of Hospitality Management, 34, 394-403.

*Stolk, P., Markwell, K., \& Jenkins, J. M. (2007). Artificial reefs as recreational scuba diving resources: a critical review of research. Journal of Sustainable Tourism, 15(4), 331350 .

*Stone, M. J., \& Petrick, J. F. (2013). The educational benefits of travel experiences: a literature review. Journal of Travel Research, 52(6), 731-744.

*Svensson, G., Svaeri, S., \& Einarsen, K. (2009a). 'Scientific identity' of scholarly journals in hospitality and tourism research: Review and evaluation.International Journal of Hospitality Management, 28(4), 631-634.

*Svensson, G., Svaeri, S., \& Einarsen, K. (2009b). Empirical characteristics' of scholarly journals in hospitality and tourism research: An assessment. International Journal of Hospitality Management, 28, 479-483.

*Swanson, K. K., \& Timothy, D. J. (2012). Souvenirs: icon of meaning, commercialization and commoditization. Tourism Management, 33, 489-499.

Tan, L. \& Ding, J. (2015). The frontier and evolution of the strategic management theory: A scientometric analysis of Strategic Management Journal, 2001-2012. Nankai Business Review International 6(1), 20-41.

*Taplin, J., Dredge, D., \& Scherrer, P. (2014). Monitoring and Evaluating colunteer tourism: a review and analytical framework. Journal of Sustainable Tourism, 22(6), 874-897.

*Thomas, R., Shaw, G., \& Page, S. J. (2011). Understanding small firms in tourism: A perspective on research trend and challenges. Tourism Management, 32, 963-976.

*Thompson, G. M. (2010). Restaurant Profitability Management The Evolution of Restaurant Revenue Management. Cornell Hospitality Quarterly, 51(3), 308-322.

*Tkaczynski, A., \& Rundle-Thiele, S. R. (2011). Event segmentation: a review and research agenda. Tourism Management, 32, 426-434.

*Tracey, J. B. (2014). A review of human resources management research: The past 10 years and implications for moving forward. International Journal of Contemporary Hospitality Management, 26(5), 679-705.

Tribe, J. (2000). Undisciplined and unsubstantiated. Annals of Tourism Research, 27(3), 809813.

Tribe, J. (2004). Knowing about tourism: Epistemological issues. In J. Phillimore \& L. Goodson (Eds.), Qualitative research in tourism: Ontologies, epistemologies and methodologies (pp. 46). New York: Routledge.

Tribe, J. (2010). Tribes, territories and networks in the tourism academy. Annals of Tourism Research, 37(1), 7-33. Tokić, K. \& Tokić, I. (2015). Bibliometric Analysis from the Perspective of a Croatian Tourism Journal. Qualitative and Quantitative Methods in Libraries (QQML) 4: 927-936.

*Tsai, H., Pan, S., \& Lee, J. (2011). Resent research in hospitality financial management. International Journal of Contemporary Hospitality Management, 23(7), 941-971.

*Tsang, N. K. F., Lee, L. Y., Qu, H. (2015). Service quality research on China's hospitality and tourism industry. International Journal of Contemporary Hospitality Management, 27(3), 473-497.

*Tsang, N. K., \& Hsu, C. H. (2011). Thirty years of research on tourism and hospitality management in China: A review and analysis of journal publications. International Journal of Hospitality Management, 30(4), 886-896.

*Verma, R. (2010). Customer-Choice Modeling in Hospitality Services: A Review of Past Research and Discussion of Some New Applications. Cornell Hospitality Quarterly.

*Vorobjovas-Pinta, O., \& Hardy, A. (2015). The evolution of gay travel research. International Journal of Tourism Research, DOI: 10.1002/jtr.2059.

*Walls, A. R., Okumus, F., Wang, Y. R., \& Kwun, D. J. W. (2011). An epistemological view of consumer experiences. International Journal of Hospitality Management, 30(1), 10-21. 
*Walton, J. K. (2009). Prospects in tourism history: evolution, state of play and future developments. Tourism Management, 30, 783-793.

*Wardle, C., \& Buckley, R. (2014). Tourism citations in other disciplines. Annals of Tourism Research, 46, 163-184.

*Watson, S. (2008). Where are we now? A review of management development issues in the hospitality and tourism sector: Implications for talent management. International Journal of Contemporary Hospitality Management, 20(7), 758-780.

*Wearing, S., \& McGehee, N. G. (2013). Volunteer tourism: A review. Tourism Management, $38,120-130$.

*Weaver, D. B., \& Lawton, L. J. (2007). Twenty years on: The state of contemporary ecotourism research. Tourism Management, 28, 1168-1179.

*Weed, M. (2009). Progress in sports tourism research? A meta-review and exploration of futures. Tourism Management, 30, 615-628.

*Weilder, B., Moyle, B., \& McLennan, C. (2012). Disciplines that influence tourism doctoral research The United States, Canada, Australia and New Zealand. Annals of Tourism Research, 39(3), 1425-1445.

*Wen, I. (2009). Factors affecting the online travel buying decision: a review. International Journal of Comtemporary Hospitality Management, 21(6), 752-766.

White, H. D., \& Griffith, B. C. (1981). Author cocitation: A literature measure of intellectual structure. Journal of the American Society for information Science, 32(3), 163-171.

White, H. D., \& McCain, K. W. (1998). Visualizing a discipline: An author co-citation analysis of information science, 1972-1995. Journal of the American society for information science, 49(4), 327-355.

*Wickham, M., Dunn, A., \& Sweeney, S. (2012). Analysis of the leading tourism journals 19992008. Annals of Tourism Research, 39(3). 1714-1718.

*Xiao, H., \& Smith, S. L. J. (2005). Source knowledge for tourism research. Annals of Tourism Research, 32(1), 272-275.

Xiao, H., \& Smith, S. L. J. (2006a). The maturation of tourism research: Evidence from a content analysis. Tourism Analysis, 10, 335-348.

*Xiao, H., \& Smith, S. L. J. (2006b). The making of tourism research Insights from a Social Sciences Journal. Annals of Tourism Research, 33(2), 490-507.

*Xiao, H., \& Smith, S. L. J. (2008). Knowledge impact- an appraisal of tourism scholarship. Annals of Tourism Research, 35(1), 62-83.

Xie, Y. (2003). Tourism and hospitality industry studies: A comparative research between China and the overseas counties. Tourism Tribune, 18, 20-25.

*Xin, S., Tribe, J., \& Chambers, D. (2013). Conceptual research in tourism. Annals of Tourism Research, 41, 66-88.

Yadav, M. S. (2010). The decline of conceptual articles and implications for knowledge development. Journal of Marketing, 74, 1-19.

*Ye, Q., Li, T., \& Law, R. (2013). A coauthorship network analysis of tourism and hospitality research collaboration. Journal of Hospitality \& Tourism Research, 37(1), 51-76.

Ye, Q., Song, H., \& Li, T. (2012). Cross-institutional collaboration networks in tourism and hospitality research. Tourism Management Perspectives, 2(3), 55-64.

*Ying, T., \& Xiao, H. (2012). Knowledge Linkage A Social Network Analysis of Tourism Dissertation Subjects. Journal of Hospitality \& Tourism Research, 36(4), 450-477.

*Yoo, M., \& Bai, B. (2013). Customer loyalty marketing research: A comparative approach between hospitality and business journals. International Journal of Hospitality Management, 33, 166-177.

*Yoo, M., Lee, S., \& Bai, B. (2011). Hospitality marketing research from 2000 to 2009. International Journal of Contemporary Hospitality Management, 23(4), 517-532.

Yoo, J. J. E., \& Weber, K. (2005). Progress in convention tourism research. Journal of Hospitality \& Tourism Research, 29(2), 194-222. 
*Yuan, Y. Y., Tseng, Y., \& Chang, C. (2014a). Tourism subfield identification via journal clustering. Annals of Tourism Research, 47, 77-95.

*Yuan, Y., Gretzel, U., \& Tseng, Y. (2014b). Revealing the nature of contemporary tourism research: Extracting common subject areas through bibliographic coupling. International Journal of Tourism Research, DOI: 10.1002/jtr.2004.

*Zeng, B., \& Ryan, C. (2012). Assisting the poor in China through tourism development: A review of research. Tourism Management, 33, 2012.

Zhang, S., Lyu, P., \& Yan, Y. (2015). Global geographical and scientometric analysis of tourism-themed research. Scientometrics 105(1): 385-401.

*Zhang, X., Song, H., \& Huang, G. Q. (2009). Tourism supply chain management: a new research agenda. Tourism Management, 30, 345-358.

Zhao, D., \& Strotmann, A. (2008). Evolution of research activities and intellectual influences in information science 1996-2005: Introducing author bibliographic-coupling analysis. Journal of the American Society for Information Science and Technology, 59(13), 2070-2086.

*Zhao, W., \& Ritchie, J. R. B. (2007). An investigation of academic leadership in tourism research: 1985-2004. Tourism Management, 28, 476-490.

*Zhong, L., Wu, B., \& Morrison, A. M. (2015). Research on China's tourism: A 35- year review and authorship analysis. International Journal of Tourism Research, 17, 25-34.

Zopiatis, A., Theocharous, A. L., \& Constanti, P. (2015). 'The past is prologue to the future': an introspective view of hospitality and tourism research. Scientometrics 102(2): 17311753.

Zupic, I., \& Čater, T. (2015). Bibliometric methods in management and organization. Organizational Research Methods, 18(3), 429-472. 


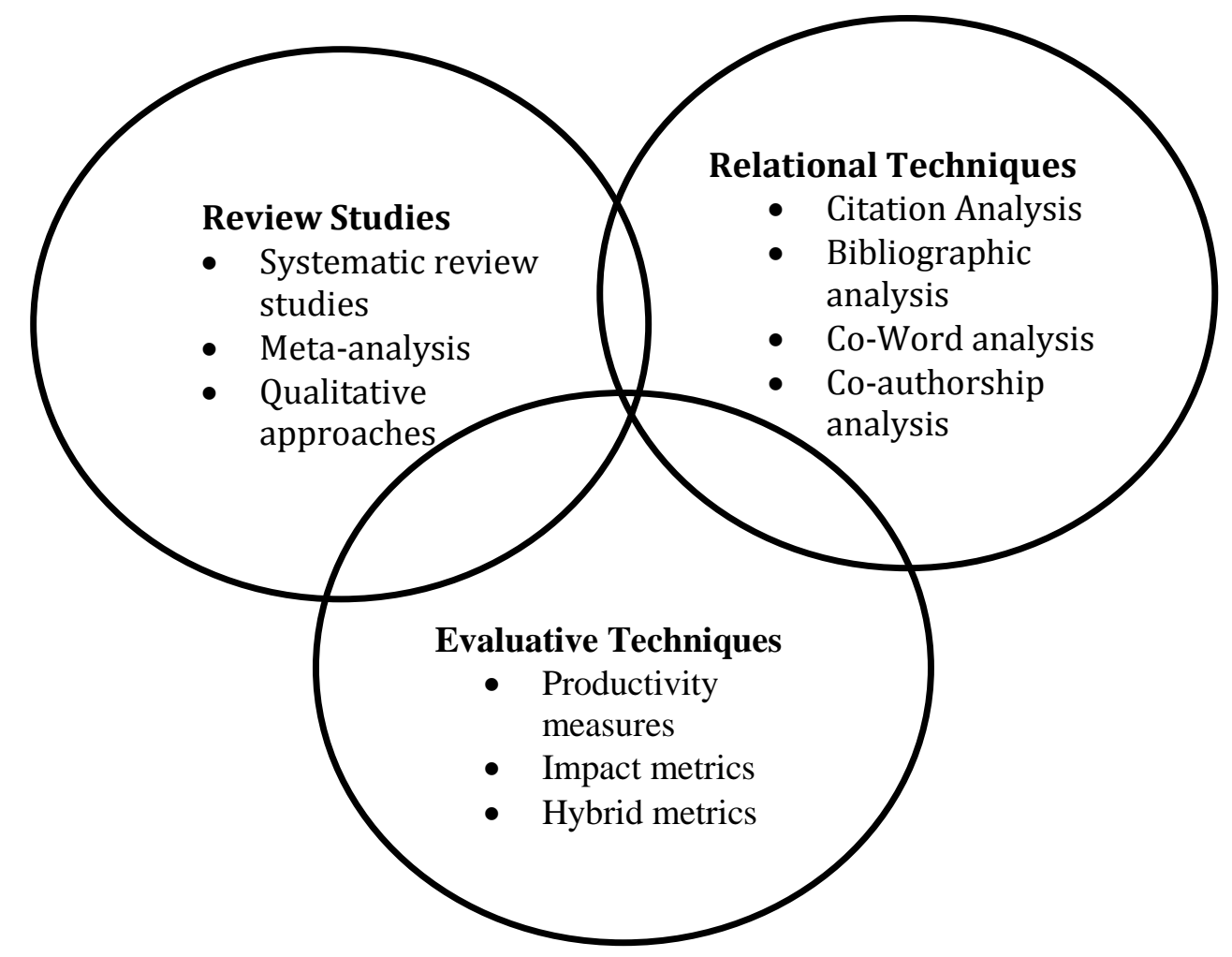

Figure 1. Bibliometric Methods 


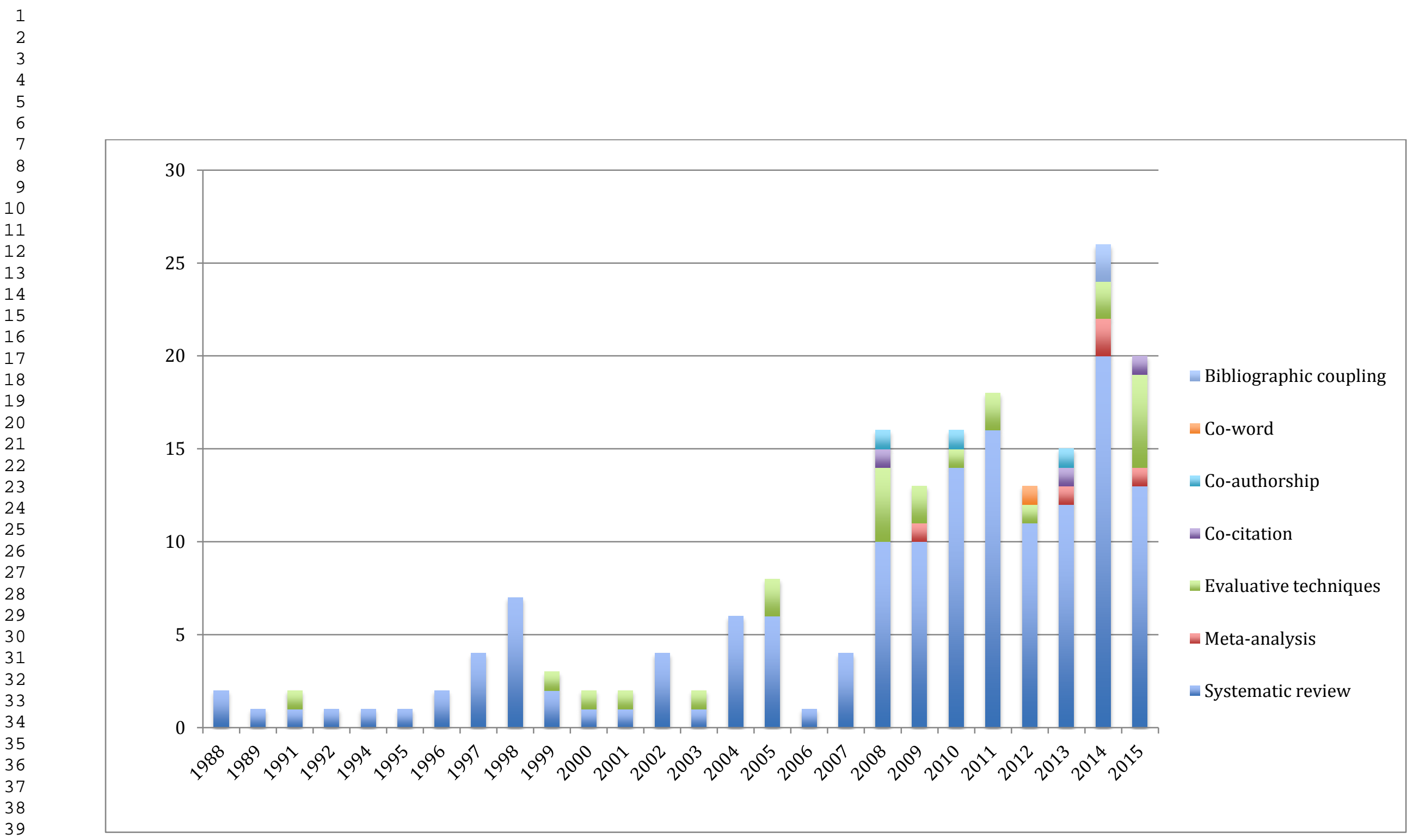

Figure 2. Distributions of Studies by Bibliometric Methods and Year 


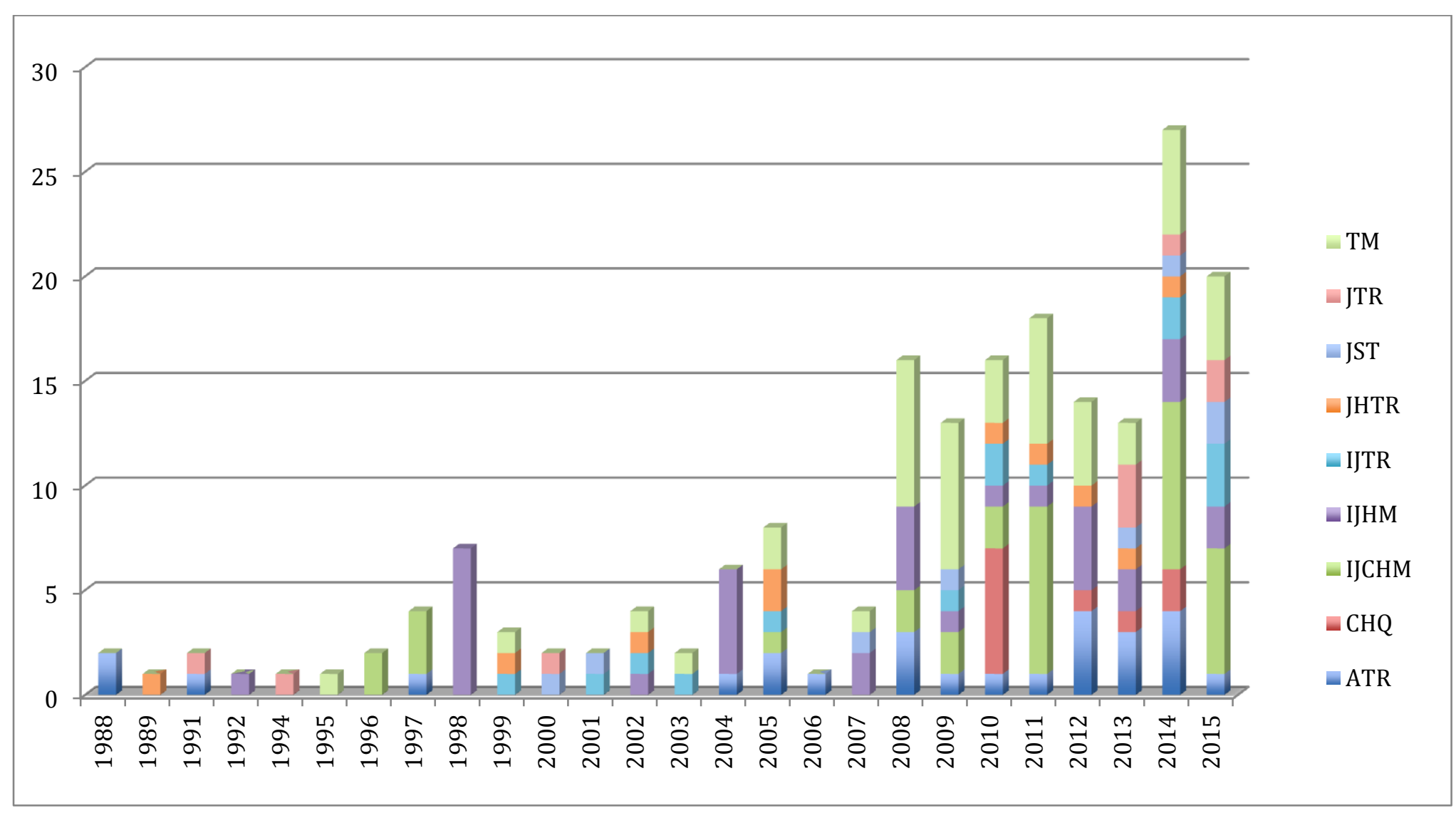

Figure 3. Distributions of Studies by Journal and Year 


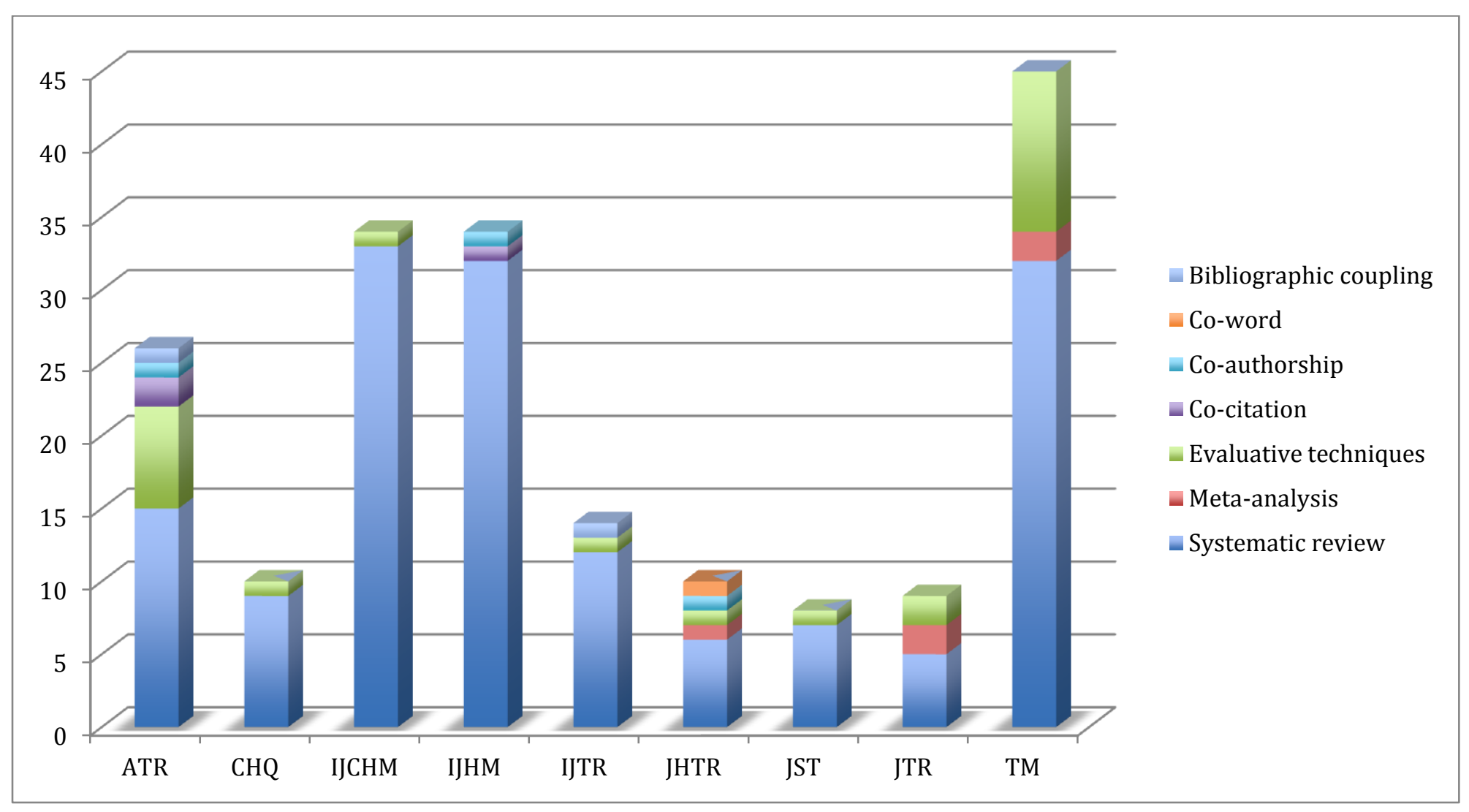

Figure 4. Distributions of Studies by Bibliometric Methods and Journals 
Table 1. Theme-focused review studies in leading hospital and tourism journals

\begin{tabular}{|c|c|c|}
\hline $\begin{array}{l}\text { Sub-Disciplines } \\
\text { Fields }\end{array}$ & Topics & Studies \\
\hline \multicolumn{3}{|c|}{ Business and Management } \\
\hline General & Management developments & Watson, 2008 \\
\hline \multirow{3}{*}{ Management } & Hotel performance & Sainaghi, 2010 \\
\hline & Hospitality quality & Crick and Spencer, 2011; Riley, 2007 \\
\hline & Sustainability issues and strategies & Aragon-Correa, Martin-Tapia, and Torre-Ruiz, 2015 \\
\hline \multirow[t]{3}{*}{$\begin{array}{l}\text { Strategic } \\
\text { Management }\end{array}$} & General & $\begin{array}{l}\text { Harrington and Ottenbacher, 2011; Harrington et al., 2014; Olsen } \\
\text { and Roper, 2015, Olsen, } 2003\end{array}$ \\
\hline & Strategy & Athiyaman, 1995 \\
\hline & Strategic planning & Phillips and Moutinho, 2014 \\
\hline Leadership & General & Pittaway et al., 1998 \\
\hline \multirow[t]{15}{*}{ Marketing } & General & $\begin{array}{l}\text { Bowen and Sparks, 1998; Dolnicar and Ring, 2014; Hu, 1996; } \\
\text { Line and Runyan, 2012; Morosan et al., 2014; Oh et al., 2004; } \\
\text { Yoo, Lee, and Bai, 2011 }\end{array}$ \\
\hline & Customer loyalty & Kandampully et al., 2015; Yoo and Bai, 2013 \\
\hline & Consumer behavior & $\begin{array}{l}\text { Wen, 2009; Kim et al., 2010; Johns and Pine, 2002; Mattila, } \\
2004\end{array}$ \\
\hline & Website evaluation studies & Ip et al., 2011; Law, Qi, and Buhalis, 2010 \\
\hline & Word-of-mouth studies & Cantallops and Salvi, 2014; Confente, 2014 \\
\hline & Destination marketing & Pike and Page, 2014 \\
\hline & Seasonality research & Koenig-Lewis and Bischoff, 2005 \\
\hline & Souvenirs & Swanson and Timothy, 2012 \\
\hline & Destination image & Pike, 2002 \\
\hline & Consumer experience & Ritchie and Hudson, 2009; Walls et al., 2011 \\
\hline & City branding & Oguztimur and Akturan, 2015 \\
\hline & Event segmentation & Tkaczynski and Rundle-Thiele, 2011 \\
\hline & Destination loyalty formation & Gursoy, Chen, and Chi, 2014 \\
\hline & Customer choice & Verma, 2010 \\
\hline & Service related & Kandampully et al., 2014 \\
\hline \multirow{5}{*}{$\begin{array}{l}\text { Small Business } \\
\text { Management } \\
\text { Information Systems }\end{array}$} & Small toursim business research & Thomas et al., 2011; Morrison et al.,2010 \\
\hline & Information technology and/or & Buhalis and Law, 2008; Kirk and Pine, 1998; O'Connor and \\
\hline & communication & $\begin{array}{l}\text { Murphy, 2004; Law et al., 2013; Law, Buhalis, and Cobanoglu, } \\
\text { 2014; Ip, Leung, and Law, } 2011\end{array}$ \\
\hline & $\begin{array}{l}\text { Knowledge transfer and } \\
\text { management }\end{array}$ & Hallin and Marnburg, 2008; Shaw and Williams, 2009 \\
\hline & Intelligent systems & Gretsel, 2011 \\
\hline \multirow[t]{2}{*}{ Entrepreneurship } & General & $\mathrm{Li}, 2008$ \\
\hline & Innovation & Hjalager, 2010 \\
\hline \multirow[t]{2}{*}{$\begin{array}{l}\text { Human resource } \\
\text { management }\end{array}$} & General & $\begin{array}{l}\text { Davidson et al., 2011; Guerrier and Deery, 1998; Kusluvan et al., } \\
\text { 2010; Lucas and Deery, 2004; Singh et al., 2007; Tracey, } 2014\end{array}$ \\
\hline & Talent management & Deery and Jago, 2015 \\
\hline \multirow{4}{*}{$\begin{array}{l}\text { Organizational } \\
\text { behavior }\end{array}$} & General & Guerrier and Deery, 1998 \\
\hline & $\begin{array}{l}\text { Abusive work practices and } \\
\text { bullying }\end{array}$ & Bloisi and Hoel, 2008 \\
\hline & Workforce diversity & Sourouklis and Tsagdis, 2013 \\
\hline & Culture & Chen et al., 2012; Li, 2014 \\
\hline Accounting & General & Harris and Brown, 1998 \\
\hline \multirow[t]{3}{*}{ Finance } & $\begin{array}{l}\text { Finance and/ or managerial } \\
\text { accounting research }\end{array}$ & Jang and Park, 2011; Tsai et al., 2011; Park and Jang, 2014 \\
\hline & Revenue management & Guillet and Mohammed, 2015; Anderson, Xie, 2010 \\
\hline & Accounting & Hesford and Potter, 2010 \\
\hline \multirow[t]{3}{*}{$\begin{array}{l}\text { Operation } \\
\text { Management }\end{array}$} & Service operations research & $\begin{array}{l}\text { Gummesson, 2014; Jones and Lockwood, 1998; O'Neill and } \\
\text { McGinley, } 2014\end{array}$ \\
\hline & Capacity management & Pullman and Rodgers, 2010 \\
\hline & Supply Chain Management & Sigala, 2013; Zhan et al., 2009 \\
\hline \multicolumn{3}{|l|}{ Economy } \\
\hline \multirow[t]{2}{*}{ Economics } & General & Mohammed et al., 2015; Song et al., 2012 \\
\hline & GDP & Castro-Nuno et al., 2013 \\
\hline \multirow[t]{3}{*}{ Demand } & Demand modeling and forecasting & Song and $\mathrm{Li}, 2008$ \\
\hline & $\begin{array}{l}\text { International tourism demand } \\
\text { forecasting }\end{array}$ & Lim, 1997; Peng et al., 2014 \\
\hline & Demand elasticity & Peng et al., 2015 \\
\hline Economic Aspects & Summer Olympics & Kasimati, 2003 \\
\hline Health & & \\
\hline Diseases & Lyme disease & Donohoe et al., 2013 \\
\hline
\end{tabular}




\begin{tabular}{|c|c|c|}
\hline Healthiness & Health and Wellness benefits & Chen and Petrick, 2013 \\
\hline Medicine & Travel Medicine & Page, 2009 \\
\hline Sociology & & \\
\hline Sociology & Sociological approaches & Cohen and Cohen, 2012 \\
\hline & Residents' attitudes to tourism & Nunkoo et al., 2013 \\
\hline & Urban tourism research & Ashworth and Page, 2011 \\
\hline & Social impacts of tourism & Deery et al., 2012 \\
\hline & Sustainable tourism & Buckley, 2012 \\
\hline & Host perceptions & Sharpley, 2014 \\
\hline & Resilience in tourism & Luthe and Wyss, 2014 \\
\hline Tourism & General & Brent et al., 2011 \\
\hline experience & $\begin{array}{l}\text { Family and Relationship benefits of } \\
\text { travel experiences }\end{array}$ & Durko and Petrick, 2013 \\
\hline & $\begin{array}{l}\text { Educational benefits of travel } \\
\text { experiences }\end{array}$ & Stone and Petrick, 2013 \\
\hline Alternative tourism & & \\
\hline Alternative Tourism & Volunteer tourism & Taplin et al., 2014; Wearing and McGehee, 2013 \\
\hline Fields & Zoo tourism & Mason, 2000 \\
\hline & Gay travel & Vorobjovas-Pinta and Hardy, 2015 \\
\hline & Film tourism & Connell, 2012 \\
\hline & Convention tourism & Yoo and Weber, 2005 \\
\hline & Sport Tourism & Hinch and Higham, 2001; Weed, 2009 \\
\hline Other sub-disciplines & & \\
\hline $\begin{array}{l}\text { Tourism Planning } \\
\text { and Policy }\end{array}$ & General & Dredge and Jamal, 2015 \\
\hline Psychology & General & Pearce and Packer, 2013 \\
\hline Geography & Geographical information systems & Bahaire and Elliott-White, 1999 \\
\hline & Geography of tourism & Hall and Page, 2009 \\
\hline History & Tourism History & Walton, 2009 \\
\hline Ecotourism & General & Weaver and Lawton, 2007 \\
\hline & Nature-based tourism & Ardoin et al., 2015 \\
\hline Event management & Event tourism & Getz, 2008 \\
\hline & $\begin{array}{l}\text { convention and meeting } \\
\text { management }\end{array}$ & Lee and Back, 2005 \\
\hline & visitor attraction research & Leask, 2010 \\
\hline Hospitality & Hospitality definitions & Morrison, 2002 \\
\hline Sustainable & Environmentally related research & Myung et al., 2012 \\
\hline environment & Artificial reefs for scuba diving & Stolket al., 2007 \\
\hline Education & Simulation in hospitality & Feinstein and Parks, 2002 \\
\hline Techniques & & \\
\hline
\end{tabular}




\section{Contribution Statement}

\section{What is the contribution to knowledge, theory, policy or practice offered by the paper?}

This article "Bibliometric Studies in Tourism" contributes to the body of knowledge as being the first study that empirically analyzes previous bibliometric studies in hospitality and tourism and proposes a research agenda for future studies. The study results indicate that many of the studies in the field were review studies conducted via (none) systematic review or a qualitative approach. These studies may be a barrier to extending the studies, as subjectivity may preclude the repeatability of such studies in social science. Hence, the current study results suggest that review studies should be supported with quantitative (relational) bibliometric approaches. Additionally, this study provides implications related to specific future research topics in the field. Not many researchers in our field are closely familiar with bibliometric analysis. Hence, this study offers opportunities and examples for all stakeholders.

\section{How does the paper offer a social science perspective / approach?}

This study clearly offers a social science perspective in relation to geographic, political, economic, sociological, and cultural areas. For example, the sample of this study was constituted from leading hospitality and tourism journals. These journals are well known among academicians and practitioners globally. Study results should be useful for institutions in making policies and providing funds in specific research arears. This study highlights specific priorities for scholars to investigate the evolution of the hospitality and tourism field. This study provides sociological perspective by establishing general concerns on how bibliometric methods have been applied and offering solutions to generate advances. Finally, this study offers a new subdiscipline to regiment and directs the regular scholarly discussions on the evolution of all the dimensions of the field. 